\title{
Hydrothermally Tailored Three-Dimensional Ni-V Layered Double Hydroxide Nanosheets as High-Performance Hybrid Supercapacitor Applications
}

Ankit Tyagi, ${ }^{\dagger}$ Manish Chandra Joshi, $^{\dagger}$ Asmita Shah, ${ }^{\dagger}$ Vijay Kumar Thakur, ${ }^{\S}$ and Raju Kumar Gupta*,†,+(0)

${ }^{\dagger}$ Department of Chemical Engineering and ${ }^{\ddagger}$ Center for Environmental Science and Engineering, Indian Institute of Technology Kanpur, Kanpur 208016, UP, India

${ }^{\S}$ School of Aerospace, Transport and Manufacturing, Enhanced Composites and Structures Center, Cranfield University, College Road, Cranfield MK43 OAL, Bedfordshire, United Kingdom

\section{Supporting Information}

ABSTRACT: Here, we report a facile and easily scalable hydrothermal synthetic strategy to synthesize $\mathrm{Ni}-\mathrm{V}$ layered double hydroxide (NiV LDH) nanosheets toward high-energy and high-power-density supercapacitor applications. NiV LDH nanosheets with varying $\mathrm{Ni-to-V}$ ratios were prepared. Threedimensional curved nanosheets of $\mathrm{Ni}_{0.80} \mathrm{~V}_{0.20} \mathrm{LDH}$ showed better electrochemical performance compared to other

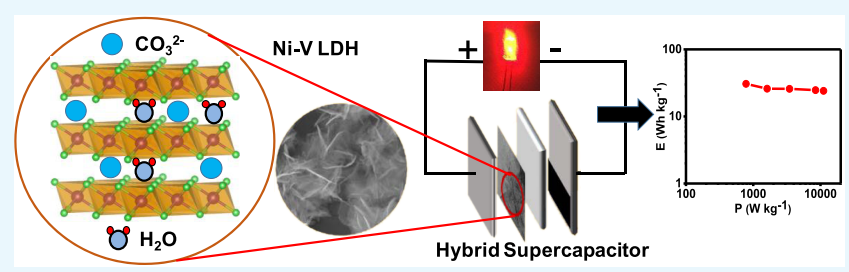
synthesized NiV LDHs. The electrode coated with $\mathrm{Ni}_{0.80} \mathrm{~V}_{0.20} \mathrm{LDH}$ nanosheets in a three-electrode cell configuration showed excellent pseudocapacitive behavior, having a high specific capacity of $711 \mathrm{C} \mathrm{g}^{-1}\left(1581 \mathrm{~F} \mathrm{~g}^{-1}\right)$ at a current density of $1 \mathrm{~A} \mathrm{~g}^{-1}$ in $2 \mathrm{M} \mathrm{KOH}$. The material showed an excellent rate capability and retained the high specific capacity of $549 \mathrm{C} \mathrm{g}^{-1}\left(1220 \mathrm{~F} \mathrm{~g}^{-1}\right)$ at a current density of $10 \mathrm{~A} \mathrm{~g}^{-1}$ and low internal resistances. Owing to its superior performance, $\mathrm{Ni}_{0.80} \mathrm{~V}_{0.20} \mathrm{LDH}$ nanosheets were used as positive electrode and commercial activated carbon was used as negative electrode for constructing a hybrid supercapacitor (HSC) device, having a working voltage of $1.5 \mathrm{~V}$. The HSC device exhibited a high specific capacitance of $98 \mathrm{~F} \mathrm{~g}^{-1}$ at a current density of $1 \mathrm{~A} \mathrm{~g}$. The HSC device showed a higher energy density of $30.6 \mathrm{Wh} \mathrm{kg}^{-1}$ at a power density of $0.78 \mathrm{~kW} \mathrm{~kg}^{-1}$ and maintained a high value of 24 $\mathrm{Wh} \mathrm{kg}{ }^{-1}$ when the power density was increased to $11.1 \mathrm{~kW} \mathrm{~kg}^{-1}$. The performance of NiV LDHs nanosheets indicates their great potential as low-cost electrode material for future energy-storage devices.

\section{INTRODUCTION}

Due to global economy development, the continuous upsurge in demand of energy gives rise to the excessive consumption of fossil fuels, which eventually has resulted in lessening of fossil fuels, environmental pollution, and global warming. ${ }^{1,2}$ To safeguard the environment from adverse impacts and meet the future energy demand, electricity generated through clean route has gained increased attention, which is one of the major thrust areas in renewable energy. ${ }^{3,4}$ Supercapacitors, also known as ultracapacitors, are one of the safe and attractive energy-storage devices over batteries and conventional capacitors due to their higher power density than batteries and higher energy density compared to conventional dielectric capacitors. $^{5}$ On the basis of charge-storage mechanisms, supercapacitors are classified as electric double-layer capacitors (EDLCs) and pseudocapacitors. ${ }^{6}$ In EDLCs, charge is stored due to electrostatic attraction between electrolyte ions at the electrode-electrolyte interface; however, charge-storage mechanism follows a Faradic reaction, i.e., charge storage takes place at the surface of active electrode material in pseudocapacitors. ${ }^{7}$ Pseudocapacitors, due to their higher energy density and specific capacitance compared to EDLCs, are more attractive candidates for future energy-storage devices. ${ }^{8}$ Transition-metal oxides like $\mathrm{Co}_{3} \mathrm{O}_{4},{ }^{9} \mathrm{MnO}_{2},{ }^{10} \mathrm{RuO}_{2},{ }^{11} \mathrm{TiO}_{2},{ }^{12} \mathrm{NiO},{ }^{13} \mathrm{Fe}_{2} \mathrm{O}_{3},{ }^{14}$ and $\mathrm{Nb}_{2} \mathrm{O}_{5} ;{ }^{15}$ conducting polymers, ${ }^{16,17}$ for example, polyaniline, polypyrrole, and polythiophene; and $\mathrm{Ni}(\mathrm{OH})_{2}$ nanoparticles $^{18,19}$ have been used in pseudocapacitors because of their superior energy density, fast redox behavior, high specific capacitance, and environment-friendly nature. Ternary metal oxides having formula $\mathrm{A}_{X} \mathrm{~B}_{3-X} \mathrm{O}_{4}$, where $\mathrm{A}$ and $\mathrm{B}$ are transition metals with spinel structures, like $\mathrm{NiCo}_{2} \mathrm{O}_{4}{ }^{20,21} \mathrm{CoFe}_{2} \mathrm{O}_{4}{ }^{22}$ $\mathrm{NiMn}_{2} \mathrm{O}_{4}{ }^{23} \mathrm{MnCo}_{2} \mathrm{O}_{4}{ }^{24} \mathrm{CuCo}_{2} \mathrm{O}_{4},{ }^{25}$ etc., have shown outstanding supercapacitive performance and excellent stability during cycling compared to their respective metal oxides mainly due to their superior electronic conductivity. ${ }^{26}$

Recently, layered double hydroxide (LDHs) materials have gained popularity as favorable electrode materials for supercapacitors owing to their high capacitance, distinctive structural properties having high surface area, fast redox reaction during charging and discharging, flexible ion

Received: December 24, 2018

Accepted: February 4, 2019

Published: February 14, 2019 
exchangeability, environment-friendly nature, and cost-effective scalability. ${ }^{27}$ LDHs are originally inorganic claylike materials having two-dimensional morphology with highly tunable hydrotalcite-like layered structure. ${ }^{28}$ LDHs contain positively charged metal hydroxide layers and weakly bonded chargebalancing anions and intercalating water molecules. ${ }^{29}$ These are represented by the general formula $\left[\mathrm{M}_{(1-X)}{ }^{2+} \mathrm{M}_{(X)}{ }^{3+}(\mathrm{OH})_{2}\right]^{X+}\left[\mathrm{A}^{n-}\right]_{X / n} \cdot m \mathrm{H}_{2} \mathrm{O}$, where $\mathrm{M}^{2+}$ and $\mathrm{M}^{3+}$ are the divalent (i.e., $\mathrm{Mg}^{2+}, \mathrm{Ni}^{2+}, \mathrm{Co}^{2+}, \mathrm{Zn}^{2+}$ ) and trivalent (i.e., $\mathrm{Fe}^{3+}, \mathrm{Al}^{3+}, \mathrm{Mn}^{3+}$ ) metal cations and $\mathrm{A}^{n-}$ are the anions, i.e., $\mathrm{OH}^{-}, \mathrm{SO}_{4}{ }^{2-}, \mathrm{CO}_{3}{ }^{2-}, \mathrm{NO}_{3}{ }^{-}, \mathrm{Cl}^{-}$, or $\mathrm{F}^{-}$. In $\mathrm{LDHs}$, water molecules are hosted in between the cationic layers as neutral molecule and hydrogen-bonded with cationic layers. ${ }^{30,31}$ The value of $X$ in LDHs crystal structure generally varies from 0.25 to 0.33 , providing the composition tunability of LDHs. ${ }^{32}$

It is worth noting from the literature that $\mathrm{LDH}$ materials have been considered as supercapacitive materials due to their resemblance of charge-storing mechanism and high power density. Brousse and co-workers showed that their chargedischarge and cyclic voltammetry (CV) profiles are different from those of pure pseudocapacitive materials, i.e., $\mathrm{MnO}_{2}$, $\mathrm{RuO}_{2}{ }^{33-35}$ Thus, LDH materials should be considered as battery-like materials. NiCo $\mathrm{LDHs}$ have attracted significant attention because of good performance as an electrode material $\left(790 \mathrm{C} \mathrm{g}^{-1}\right.$ at $\left.2 \mathrm{~A} \mathrm{~g}^{-1}\right){ }^{36}$ Chen and co-authors reported a specific capacitance of $2498 \mathrm{~F} \mathrm{~g}^{-1}$ at $1 \mathrm{~A} \mathrm{~g}^{-1}$ current density for nitrogen-doped mesoporous carbon/NiCo LDHs composite. ${ }^{37}$ Wang et al. achieved a specific capacitance of $2762 \mathrm{~F} \mathrm{~g}^{-1}(1243$ $\mathrm{C} \mathrm{g}^{-1}$ ) at a current density of $1 \mathrm{~A} \mathrm{~g}^{-138} \cdot \mathrm{CoAl} \mathrm{LDH} /$ graphene composites have achieved a specific capacitance of $479 \mathrm{~F} \mathrm{~g}^{-1}$ at a current density of $1 \mathrm{~A} \mathrm{~g}^{-1} \cdot{ }^{39}$ Bai et al. reported carbon nanotube/NiAl $\mathrm{LDH}$ composites and showed a specific capacitance of $694 \mathrm{~F} \mathrm{~g}^{-1}$ at a current density of $1 \mathrm{~A} \mathrm{~g}^{-1}$. Atomically thin NiFe LDH three-dimensional (3D) microspheres showed a specific capacitance of $1061 \mathrm{~F} \mathrm{~g}^{-1}$ at a current density of $1 \mathrm{~A} \mathrm{~g} \mathrm{~g}^{-1} \cdot{ }^{41} \mathrm{Lv}$ et al. reported glucoseinterclated $\mathrm{NiMn} \mathrm{LDH}$ materials and showed a specific capacitance of $1464 \mathrm{~F} \mathrm{~g}^{-1}$ at a current density of $0.5 \mathrm{~A} \mathrm{~g}^{-1}$, whereas pristine $\mathrm{NiMn} \mathrm{LDH}$ showed only $852 \mathrm{~F} \mathrm{~g}^{-1}{ }^{42} \mathrm{MgAl}$ $\mathrm{LDH} /$ reduced graphene oxide nanocomposite showed a specific capacitance of $1334 \mathrm{~F} \mathrm{~g}^{-1}$ at a current density of $1 \mathrm{~A}$ $\mathrm{g}^{-1.43}$ To the best of our knowledge, there is no study available over hydrothermally tailored nickel-vanadium layered double hydroxide (NiV LDHs) materials for supercapcitor application.

Herein, we report the syntheis of $\mathrm{NiV} \mathrm{LDH}$ nanosheets having various compositions based on the amount of $\mathrm{Ni}$ and $\mathrm{V}$ $\left(\mathrm{Ni}_{0.67} \mathrm{~V}_{0.33} \mathrm{LDH}, \mathrm{Ni}_{0.75} \mathrm{~V}_{0.25} \mathrm{LDH}\right.$, and $\left.\mathrm{Ni}_{0.80} \mathrm{~V}_{0.20} \mathrm{LDH}\right)$ using a simple, low-cost, and potentially scalable hydrothermal technique. The as-prepared NiV LDH nanosheets were coated on $\mathrm{Ni}$ foam and used as supercapacitor electrode. Scanning electron microscopy (SEM), transmission electron microscopy (TEM), X-ray diffraction (XRD), Brunauer-Emmett-Teller (BET), and X-ray photoelectron spectroscopy (XPS) techniques were used for their morphological, structural, and physical characterizations, while electrochemical characterization techniques such as $\mathrm{CV}$, galvanostatic charge-discharge (GCD), and electrochemical impedance spectroscopy (EIS) were used to study the electrochemical properties of $\mathrm{NiV} \mathrm{LDH}$ nanosheets. Electrochemical characterizations of $\mathrm{NiV} \mathrm{LDH}$ nanosheets display outstanding pseudocapacitance performance for $\mathrm{Ni}_{0.80} \mathrm{~V}_{0.20} \mathrm{LDH}$. A high specific capacity of $711 \mathrm{C} \mathrm{g}^{-1}$ $\left(1581 \mathrm{~F} \mathrm{~g} \mathrm{~g}^{-1}\right)$ was achieved at a current density of $1 \mathrm{~A} \mathrm{~g}^{-1}$, which remained $549 \mathrm{C} \mathrm{g}^{-1}\left(1220 \mathrm{~F} \mathrm{~g}^{-1}\right)$ at a higher current density of $10 \mathrm{~A} \mathrm{~g}^{-1}$. Moreover, a hybrid supercapacitor (HSC) device with a working potential of $1.5 \mathrm{~V}$ was fabricated using $\mathrm{Ni}_{0.80} \mathrm{~V}_{0.20} \mathrm{LDH}$ as positive electrode and commercial activated carbon as negative electrode. The HSC device exhibited a higher energy density of $30.6 \mathrm{Wh} \mathrm{kg}^{-1}$ at a power density of $0.78 \mathrm{~kW} \mathrm{~kg}^{-1}$, which remained at $24 \mathrm{Wh} \mathrm{kg}^{-1}$ at a high power density of $11.1 \mathrm{~kW} \mathrm{~kg}^{-1}$. This work suggests that the $\mathrm{Ni}_{0.80} \mathrm{~V}_{0.20}$ $\mathrm{LDH}$ material can be an excellent candidate for improving the energy density of the HSC device.

\section{RESULTS AND DISCUSSION}

\subsection{Structural and Morphological Characterization.} Figure 1 shows typical XRD patterns of $\mathrm{Ni}_{0.67} \mathrm{~V}_{0.33} \mathrm{LDH}$,

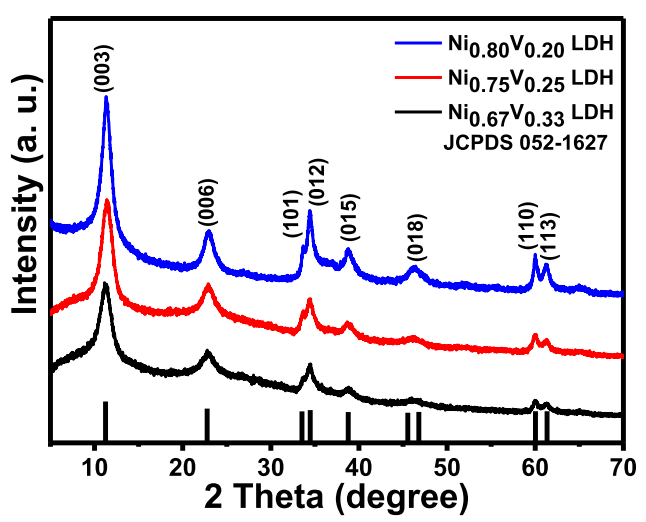

Figure 1. XRD patterns of $\mathrm{Ni}_{0.67} \mathrm{~V}_{0.33} \mathrm{LDH}, \mathrm{Ni}_{0.75} \mathrm{~V}_{0.25} \mathrm{LDH}$, and $\mathrm{Ni}_{0.80} \mathrm{~V}_{0.20} \mathrm{LDH}$.

$\mathrm{Ni}_{0.75} \mathrm{~V}_{0.25} \mathrm{LDH}$, and $\mathrm{Ni}_{0.80} \mathrm{~V}_{0.20}$ LDH. The XRD spectra of $\mathrm{Ni}_{0.67} \mathrm{~V}_{0.33}$ LDH, $\mathrm{Ni}_{0.75} \mathrm{~V}_{0.25}$ LDH, and $\mathrm{Ni}_{0.80} \mathrm{~V}_{0.20} \mathrm{LDH}$ matched well with the standard nickel-vanadium carbonate hydroxide hydrate (JCPDS 052-1627). The characteristic peaks of the as-synthesized $\mathrm{NiV}$ LDHs at 11.25, 22.78, $33.54,34.47,38.78,45.55,46.79,60.03$, and $61.34^{\circ}$ with respect to their corresponding $(h \mathrm{kl})$ planes of (003), (006), (101), (012), (015), (018), (0012), (110), and (113) indicate the $\mathrm{LDH}$ formation during the hydrothermal synthesis (Scheme 1). It can be noted that there was no peak appearance for impurities found in the recorded spectra. Crystallinity of $\mathrm{Ni}_{0.80} \mathrm{~V}_{0.20} \mathrm{LDH}$ was higher compared to $\mathrm{Ni}_{0.67} \mathrm{~V}_{0.33} \mathrm{LDH}$ and $\mathrm{Ni}_{0.75} \mathrm{~V}_{0.25} \mathrm{LDH}$ (Table S1). ${ }^{44}$ In addition, the interlayer distances for the $d_{003}$ plane calculated form Bragg's formula were found to be approximately $0.77,0.78$, and $0.79 \mathrm{~nm}$ in $\mathrm{Ni}_{0.67} \mathrm{~V}_{0.33} \mathrm{LDH}, \mathrm{Ni}_{0.75} \mathrm{~V}_{0.25} \mathrm{LDH}$, and $\mathrm{Ni}_{0.80} \mathrm{~V}_{0.20}$ $\mathrm{LDH}$, respectively. ${ }^{45}$ Literature studies suggest that $\alpha$ phase of LDHs have larger interlayer spacing than $\beta$ phase of LDHs $(0.46 \mathrm{~nm})$, which was used to store more neutral water molecules and carbonate anions at the interlayers. ${ }^{46}$ Thus, theoretically, $\alpha$ phase LDHs can be more electrochemically active than $\beta$ phase LDHs. ${ }^{47,48}$ The XRD spectra for pure Ni hydroxide and V-based hydroxide are given in Figure S1, which shows that the XRD spectra of the former matched nicely with pure hexagonal $\alpha-\mathrm{Ni}(\mathrm{OH})_{2}$ (JCPDS file 38-0715). However, different characteristics are observed for the latter due to its low crystallinity. Surface morphologies of $\mathrm{Ni}_{0.67} \mathrm{~V}_{0.33} \mathrm{LDH}$, $\mathrm{Ni}_{0.75} \mathrm{~V}_{0.25} \mathrm{LDH}$, and $\mathrm{Ni}_{0.80} \mathrm{~V}_{0.20} \mathrm{LDH}$ were investigated by field emission SEM (FESEM) images. Figure $2 \mathrm{a}-\mathrm{f}$ shows threedimensional morphology composed of curved nanosheets for all NiV LDHs. ${ }^{41}$ The morphologies of Ni hydroxide and Vbased hydroxides are shown in Figure S2. To understand the 
Scheme 1. Synthesis of NiV LDH and Fabrication of HSC
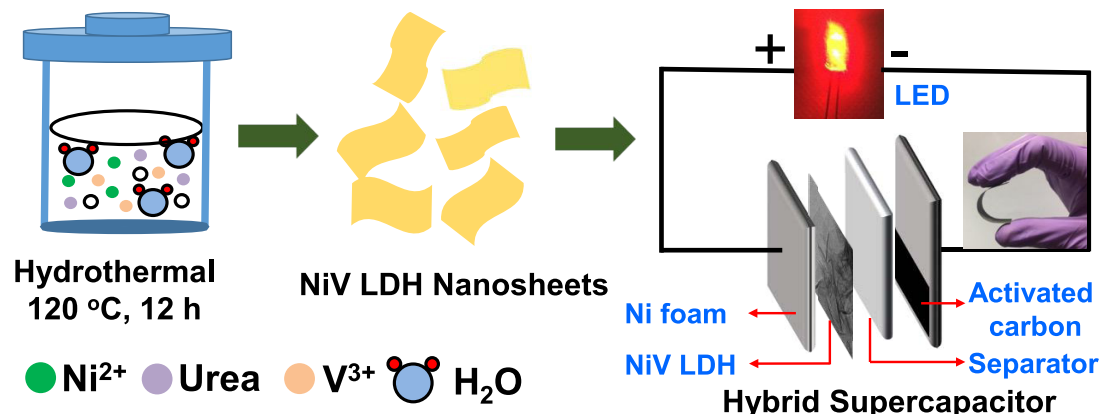

Hybrid Supercapacitor
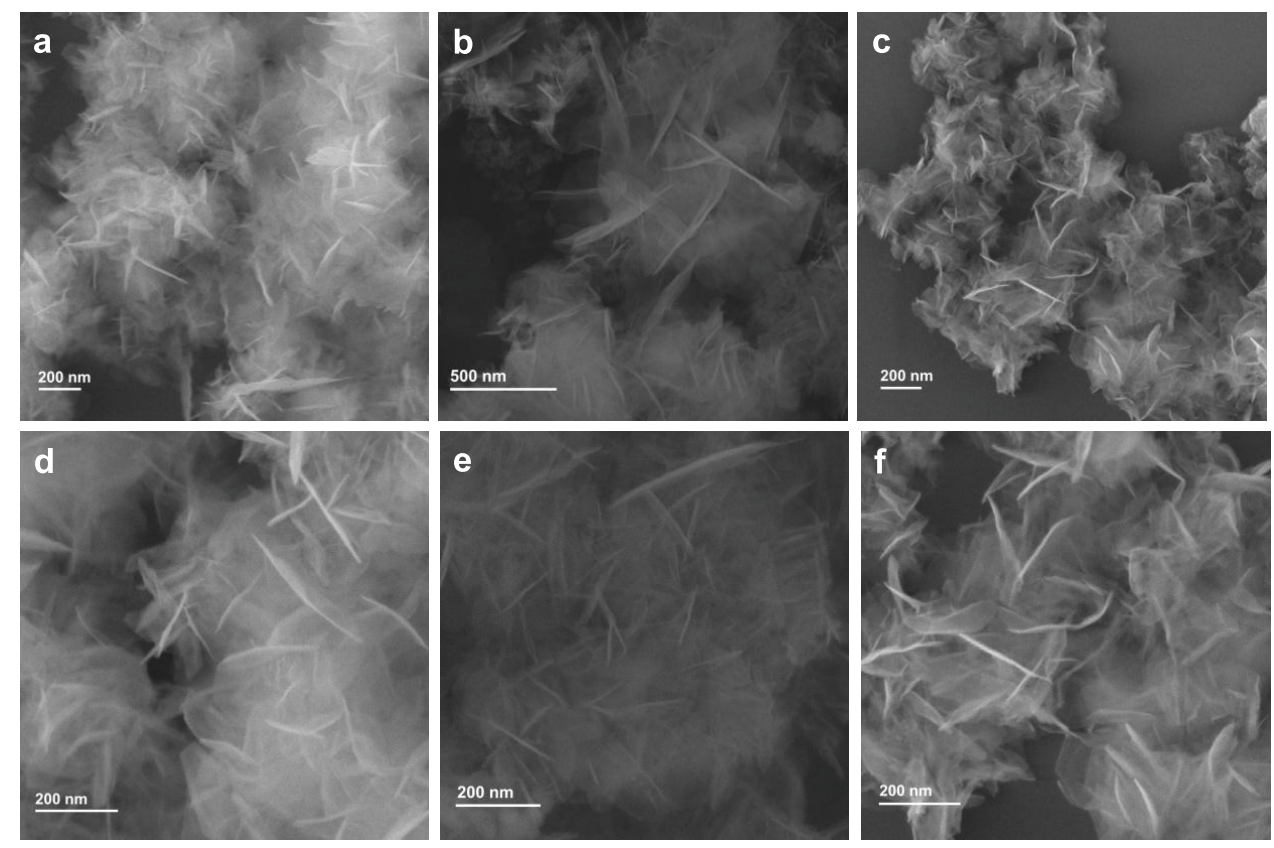

Figure 2. ((a, d), (b, e), and (c, f)) Low- and high-magnification FESEM images of $\mathrm{Ni}_{0.67} \mathrm{~V}_{0.33} \mathrm{LDH}, \mathrm{Ni}_{0.75} \mathrm{~V}_{0.25} \mathrm{LDH}$, and $\mathrm{Ni}_{0.80} \mathrm{~V}_{0.20} \mathrm{LDH}$, respectively.
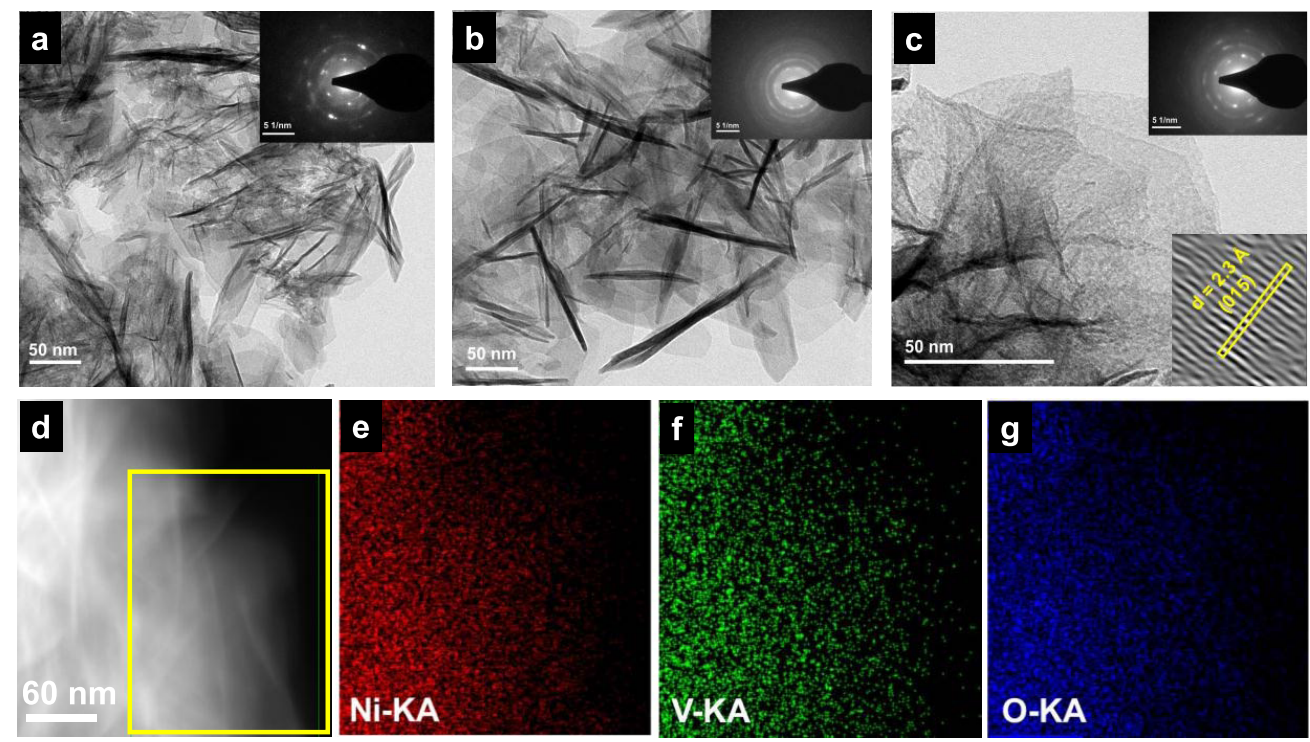

Figure 3. $(\mathrm{a}-\mathrm{c})$ TEM images of $\mathrm{Ni}_{0.67} \mathrm{~V}_{0.33} \mathrm{LDH}, \mathrm{Ni}_{0.75} \mathrm{~V}_{0.25} \mathrm{LDH}$, and $\mathrm{Ni}_{0.80} \mathrm{~V}_{0.20} \mathrm{LDH}$, respectively, and the insets show their corresponding SAED patterns, as well as the HRTEM image of $\mathrm{Ni}_{0.80} \mathrm{~V}_{0.20} \mathrm{LDH}$. (d) TEM image of $\mathrm{Ni}_{0.80} \mathrm{~V}_{0.20} \mathrm{LDH}$. (e-g) Elemental mapping for $\mathrm{Ni}$, V, and O corresponding to the area selected in (d). 

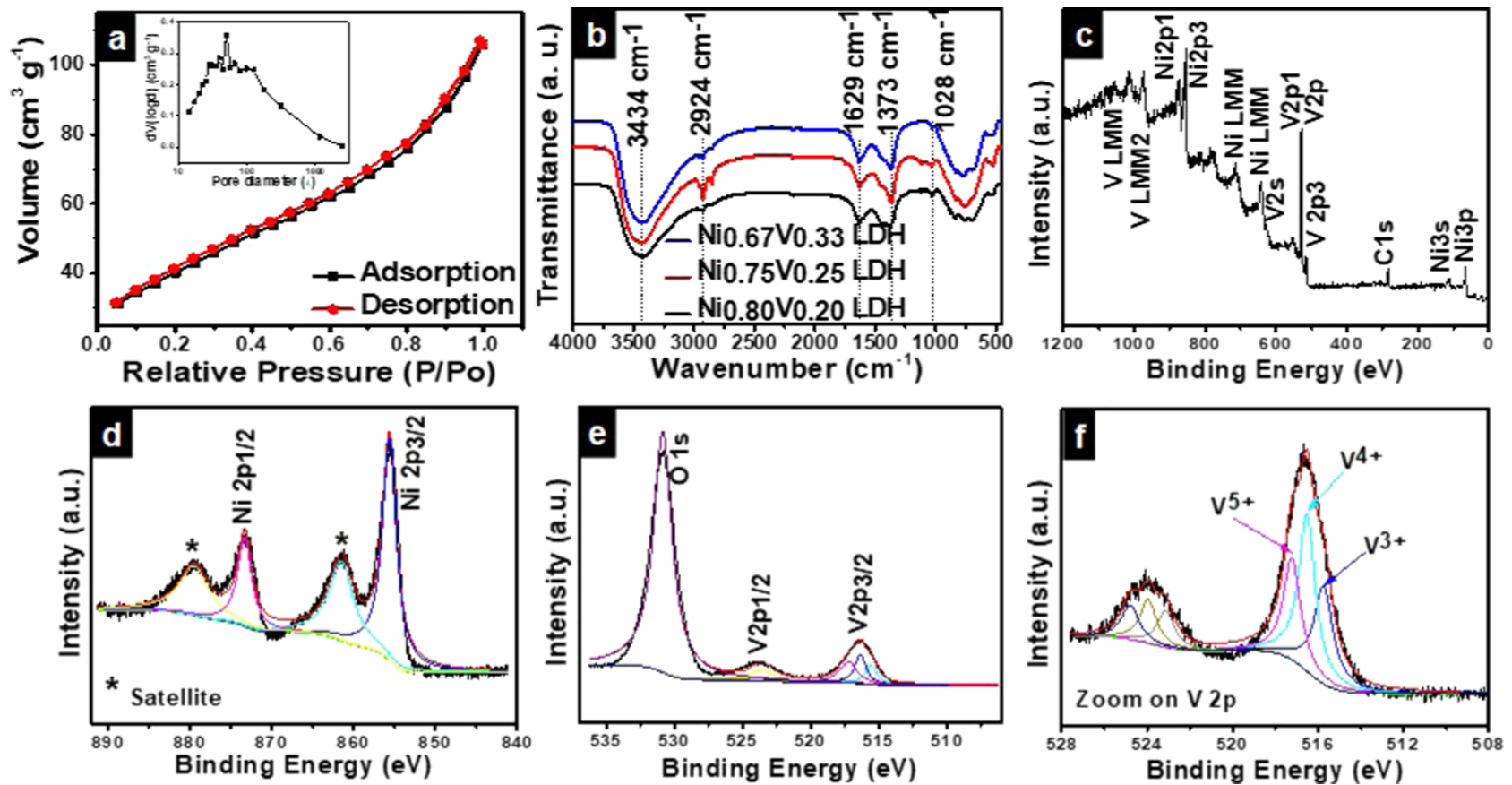

Figure 4. (a) Nitrogen adsorption-desorption isotherm of $\mathrm{Ni}_{0.80} \mathrm{~V}_{0.20} \mathrm{LDH}$; the inset of (a) shows the $\mathrm{BJH}$ pore size distribution of $\mathrm{Ni}_{0.80} \mathrm{~V}_{0.20}$ LDH. (b) FTIR curves for $\mathrm{Ni}_{0.67} \mathrm{~V}_{0.33} \mathrm{LDH}, \mathrm{Ni}_{0.75} \mathrm{~V}_{0.25} \mathrm{LDH}$, and $\mathrm{Ni}_{0.80} \mathrm{~V}_{0.20} \mathrm{LDH}$;. (c) XPS survey scan for various elements for $\mathrm{Ni}_{0.80} \mathrm{~V}_{0.20} \mathrm{LDH}$. (d) Ni $2 p$ core-level spectra for $\mathrm{Ni}_{0.80} \mathrm{~V}_{0.20} \mathrm{LDH}$. (e) O 1s and V 2p core-level spectra for $\mathrm{Ni}_{0.80} \mathrm{~V}_{0.20} \mathrm{LDH}$. (f) Zoom on V 2p core-level spectra for $\mathrm{Ni}_{0.80} \mathrm{~V}_{0.20} \mathrm{LDH}$.

layer stacking and its respective morphology of the assynthesized NiV LDHs, TEM studies were carried out. Figure $3 \mathrm{a}-\mathrm{c}$ shows the TEM images of $\mathrm{Ni}_{0.67} \mathrm{~V}_{0.33} \mathrm{LDH}, \mathrm{Ni}_{0.75} \mathrm{~V}_{0.25}$ $\mathrm{LDH}$, and $\mathrm{Ni}_{0.80} \mathrm{~V}_{0.20} \mathrm{LDH}$, respectively. The TEM images confirm that the nanosheets' thickness decreases as the amount of $\mathrm{Ni}$ content is increased in the NiV LDHs, and it is observed that $1-2 \mathrm{~nm}$ thick nanosheets were formed for $\mathrm{Ni}_{0.80} \mathrm{~V}_{0.20}$ $\mathrm{LDH}$. Selected area electron diffraction (SAED) patterns (inset of Figure $3 \mathrm{a}-\mathrm{c}$ ) confirm the polycrystalline behavior of all NiV LDH materials. Figures $3 \mathrm{~d}-\mathrm{g}$ and $\mathrm{S} 3$ confirm the uniform distribution of $\mathrm{Ni}, \mathrm{V}$, and $\mathrm{O}$ in the nanosheets of $\mathrm{Ni}_{0.80} \mathrm{~V}_{0.20}$ LDH. The inset of Figure $3 \mathrm{c}$ shows the highresolution TEM (HRTEM) image of $\mathrm{Ni}_{0.80} \mathrm{~V}_{0.20} \mathrm{LDH}$, having the $d$-spacing of crystal lattice fringes to be $0.23 \mathrm{~nm}$, which is assigned to the (015) plane of NiV LDH. This was consistent with the XRD result. ${ }^{49}$ Figure $4 \mathrm{a}$ shows the nitrogen adsorption-desorption isotherm for $\mathrm{Ni}_{0.80} \mathrm{~V}_{0.20} \mathrm{LDH}$. Nitrogen adsorption-desorption isotherms for $\mathrm{Ni}_{0.67} \mathrm{~V}_{0.33} \mathrm{LDH}$ and $\mathrm{Ni}_{0.75} \mathrm{~V}_{0.25} \mathrm{LDH}$ are presented in Figure S4. The shape of the nitrogen adsorption-desorption curve was found to be type III isotherm with $\mathrm{H} 1$ hysteresis loop for all $\mathrm{NiV} \mathrm{LDH}$ materials, confirming their mesoporous nature. The BET surface areas was found to be 111,144 , and $266 \mathrm{~m}^{2} \mathrm{~g}^{-1}$ for $\mathrm{Ni}_{0.67} \mathrm{~V}_{0.33} \mathrm{LDH}$, $\mathrm{Ni}_{0.75} \mathrm{~V}_{0.25} \mathrm{LDH}$, and $\mathrm{Ni}_{0.80} \mathrm{~V}_{0.20} \mathrm{LDH}$ materials, respectively. The Barrett-Joyner-Halenda (BJH) pore size distribution curve in the inset of Figure 4a shows that pores are in the size range of $1-10 \mathrm{~nm}$ for all $\mathrm{LDH}$ materials, along with pore volumes of $0.140,0.155$, and $0.336 \mathrm{~cm}^{3} \mathrm{~g}^{-1}$ for $\mathrm{Ni}_{0.67} \mathrm{~V}_{0.33}$ $\mathrm{LDH}, \mathrm{Ni}_{0.75} \mathrm{~V}_{0.25} \mathrm{LDH}$, and $\mathrm{Ni}_{0.80} \mathrm{~V}_{0.20} \mathrm{LDH}$, respectively. Most of the pores lie in the mesoporous range of $2-50 \mathrm{~nm}$, thereby enhancing the electrochemical performance of the $\mathrm{NiV}$ LDHs. ${ }^{50}$ The BET surface area is higher for $\mathrm{Ni}_{0.80} \mathrm{~V}_{0.20} \mathrm{LDH}$ due to its more exfoliated morphology compared to $\mathrm{Ni}_{0.67} \mathrm{~V}_{0.33}$ LDH and $\mathrm{Ni}_{0.75} \mathrm{~V}_{0.25} \mathrm{LDH}$, as supported by FESEM studies. Fourier transform infrared (FTIR) analysis was carried out to know the bonding between the interlayers of LDHs. The FTIR spectra of $\mathrm{Ni}_{0.67} \mathrm{~V}_{0.33} \mathrm{LDH}, \mathrm{Ni}_{0.75} \mathrm{~V}_{0.25} \mathrm{LDH}$, and $\mathrm{Ni}_{0.80} \mathrm{~V}_{0.20}$ $\mathrm{LDH}$ are shown in Figure $4 \mathrm{~b}$. The broad and strong absorption bands in Figure $4 \mathrm{~b}$ at 3434 and $1629 \mathrm{~cm}^{-1}$ indicate the presence of stretching and bending modes of hydroxyl groups, arising from interlayer water molecules and metal-hydroxyl groups. ${ }^{51}$ Interlayer anion $\mathrm{CO}_{3}{ }^{2-}$ was confirmed through the presence of a vibration band at $\sim 1373 \mathrm{~cm}^{-1}$. The band at 2924 $\mathrm{cm}^{-1}$ was assigned to the $\mathrm{CO}_{3}{ }^{2-}-\mathrm{H}_{2} \mathrm{O}$ stretching vibration, confirming the presence of hydrogen-bonded water molecules with carbonate anions in the interlayers of NiV LDHs. ${ }^{52} \mathrm{~A}$ shoulder band at $\sim 1028 \mathrm{~cm}^{-1}$ confirms the vibration band of hydroxyl groups, which are mainly corresponding to metal cations $\left(\mathrm{Ni}^{2+}\right.$ and $\left.\mathrm{V}^{3+}\right)$. Bands at lower wavenumbers (less than $800 \mathrm{~cm}^{-1}$ ) were noted due to the stretching vibrations of metal-oxygen bonds present in $\mathrm{NiV}$ LDHs. ${ }^{53,54}$ Figure $4 \mathrm{c}-\mathrm{f}$ shows the XPS survey scan and the corresponding core-level spectra of $\mathrm{Ni}_{0.80} \mathrm{~V}_{0.20} \mathrm{LDH}$. In this figure, two peaks at $\sim 855.6$ and $\sim 873.3 \mathrm{eV}$ correspond to $\mathrm{Ni} 2 \mathrm{p}_{3 / 2}$ and $\mathrm{Ni} 2 \mathrm{p}_{1 / 2}$, respectively, and are found along with two satellite peaks at $\sim 861.6$ and $\sim 879.5 \mathrm{eV}$, indicating the native characteristic of $\mathrm{Ni}^{2+}$ spectra. ${ }^{55,56}$ The difference between the binding energies of the $\mathrm{Ni} 2 \mathrm{p}_{3 / 2}$ and $\mathrm{Ni} 2 \mathrm{p}_{1 / 2}$ peaks was found to be $\sim 17.7$ $\mathrm{eV}{ }^{57,58}$ Figure $4 \mathrm{e}$ shows the $\mathrm{O} 1 \mathrm{~s}$ and V $2 \mathrm{p}$ spectra, which confirm the $\mathrm{O} 1 \mathrm{~s}$ core-level peak at $\sim 530.9 \mathrm{eV}$. The V $2 \mathrm{p}$ spectrum also confirms the presence of $\mathrm{V} 2 \mathrm{p}_{1 / 2}$ and $\mathrm{V} 2 \mathrm{p}_{3 / 2}$ peaks due to the spinning $\mathrm{p}$ orbital splitting. The difference between the binding energies of $\mathrm{V} 2 \mathrm{p}_{1 / 2}$ and $\mathrm{V} 2 \mathrm{p}_{3 / 2}$ is found to be $\sim 7.5 \mathrm{eV}^{59} \mathrm{~V} 2 \mathrm{p}_{3 / 2}$ spectrum in Figure $4 \mathrm{f}$ can be deconvoluted into three peaks, corresponding to $\mathrm{V}$ (III) $(\sim 515.7 \mathrm{eV}), \mathrm{V}(\mathrm{IV})(\sim 516.5 \mathrm{eV})$, and V $(\mathrm{V})(\sim 517.2 \mathrm{eV})$. This confirms that $\mathrm{V}$ is partially oxidized to +4 and +5 oxidation states during hydrothermal treatment. ${ }^{60,61} \mathrm{~A}$ similar behavior was evidenced from the XPS images of $\mathrm{Ni}_{0.67} \mathrm{~V}_{0.33}$ $\mathrm{LDH}$ and $\mathrm{Ni}_{0.75} \mathrm{~V}_{0.25} \mathrm{LDH}$ (Figures S5 and S6). 

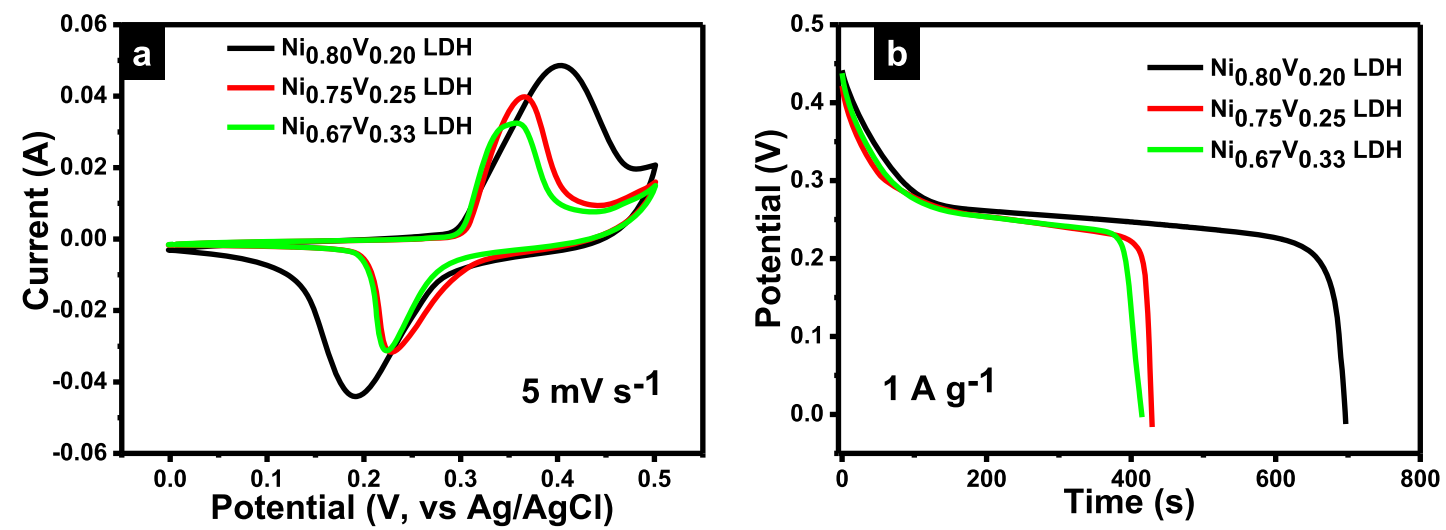

Figure 5. (a) Comparison of $\mathrm{CV}$ curves at $5 \mathrm{mV} \mathrm{s}^{-1}$ scan rate for $\mathrm{Ni}_{0.67} \mathrm{~V}_{0.33} \mathrm{LDH}, \mathrm{Ni}_{0.75} \mathrm{~V}_{0.25} \mathrm{LDH}$, and $\mathrm{Ni}_{0.80} \mathrm{~V}_{0.20} \mathrm{LDH}$. (b) Comparison of GCD curves at $1 \mathrm{~A} \mathrm{~g}^{-1}$ current density for $\mathrm{Ni}_{0.67} \mathrm{~V}_{0.33} \mathrm{LDH}, \mathrm{Ni}_{0.75} \mathrm{~V}_{0.25} \mathrm{LDH}$, and $\mathrm{Ni}_{0.80} \mathrm{~V}_{0.20} \mathrm{LDH}$.
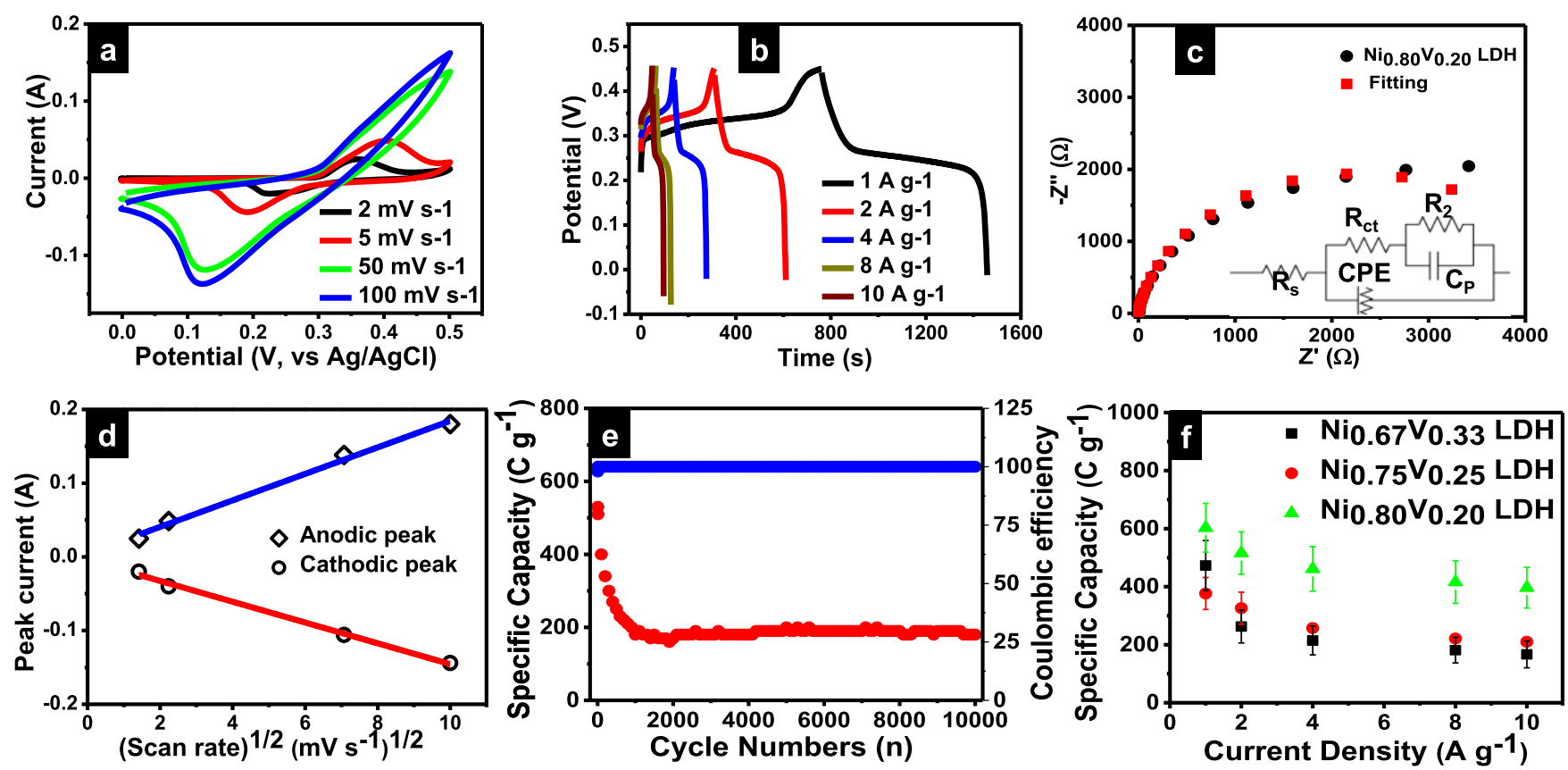

Figure 6. (a) CV curves for $\mathrm{Ni}_{0.80} \mathrm{~V}_{0.20} \mathrm{LDH}$ at various scan rates. (b) GCD curves for $\mathrm{Ni}_{0.80} \mathrm{~V}_{0.20} \mathrm{LDH}$ at various current densities. (c) EIS curve for $\mathrm{Ni}_{0.80} \mathrm{~V}_{0.20} \mathrm{LDH}$. (d) Peak current verses scan rate for $\mathrm{Ni}_{0.80} \mathrm{~V}_{0.20} \mathrm{LDH}$. (e) Specific capacity retention and Coulombic efficiency with number of cycles for $\mathrm{Ni}_{0.80} \mathrm{~V}_{0.20} \mathrm{LDH}$. (f) Specific capacity variation with current density for $\mathrm{Ni}_{0.67} \mathrm{~V}_{0.33} \mathrm{LDH}, \mathrm{Ni}_{0.75} \mathrm{~V}_{0.25} \mathrm{LDH}$, and $\mathrm{Ni}_{0.80} \mathrm{~V}_{0.20} \mathrm{LDH}$.

\section{ELECTROCHEMICAL CHARACTERIZATION}

3.1. Three-Electrode Testing. A three-electrode set up was used to investigate the electrochemical performance of assynthesized $\mathrm{Ni}_{0.67} \mathrm{~V}_{0.33} \mathrm{LDH}, \mathrm{Ni}_{0.75} \mathrm{~V}_{0.25} \mathrm{LDH}$, and $\mathrm{Ni}_{0.80} \mathrm{~V}_{0.20}$ $\mathrm{LDH}$. CV studies were carried out for the potential window of $0-0.5 \mathrm{~V}$ in the presence of $2 \mathrm{M} \mathrm{KOH}$ aqueous electrolyte. Figure 5 a shows the comparison of $\mathrm{CV}$ curves at $5 \mathrm{mV} \mathrm{s}^{-1}$ scan rate for $\mathrm{Ni}_{0.67} \mathrm{~V}_{0.33} \mathrm{LDH}, \mathrm{Ni}_{0.75} \mathrm{~V}_{0.25} \mathrm{LDH}$, and $\mathrm{Ni}_{0.80} \mathrm{~V}_{0.20} \mathrm{LDH}$, respectively. From the $\mathrm{CV}$ curves in Figure $5 \mathrm{a}$, it can be inferred that composition of $\mathrm{NiV} \mathrm{LDHs} \mathrm{influences} \mathrm{redox} \mathrm{peak}$ position as the peak shifts toward positive voltage while varying the compositions of $\mathrm{Ni}$ and $\mathrm{V}$ from $2: 1$ to $4: 1$. In addition, $\mathrm{CV}$ curves show a couple of distinct redox peaks for all NiV LDHs. At the same time, it was proved from galvanostatic discharge curves in Figure $5 b$ that appearance of nonlinear shape for all of the NiV LDHs exemplifies the quasi-reversible electron transfer between electrode material and electrolyte ions, which further confirms that the measured specific capacitances arise through redox mechanism. ${ }^{37,62}$ Evidently, the integral area under the $\mathrm{CV}$ curve of $\mathrm{Ni}_{0.80} \mathrm{~V}_{0.20} \mathrm{LDH}$ was comparatively larger than that for $\mathrm{Ni}_{0.67} \mathrm{~V}_{0.33} \mathrm{LDH}$ and $\mathrm{Ni}_{0.75} \mathrm{~V}_{0.25} \mathrm{LDH}$, revealing its better supercapacitive performance. Supporting the previous claim, the longer discharge time for $\mathrm{Ni}_{0.80} \mathrm{~V}_{0.20}$ LDH compared to $\mathrm{Ni}_{0.67} \mathrm{~V}_{0.33} \mathrm{LDH}$ and $\mathrm{Ni}_{0.75} \mathrm{~V}_{0.25} \mathrm{LDH}$ also infers its better supercapacitive performance. In addition, the characteristics of the $\mathrm{CV}$ curve for $\mathrm{Ni}_{0.80} \mathrm{~V}_{0.20} \mathrm{LDH}$ did not change much even after the scan rate was increased from 2 to $100 \mathrm{mV} \mathrm{s}^{-1}$ (Figure 6a). The CV curve suggests that redox current increases as the scan rate increases. Also, as the scan rate is increased, the anodic and cathodic peaks of LDH shift further toward positive and negative sides, respectively, indicating the reversible Faradic process. The redox peaks in the $\mathrm{CV}$ curves were due to the surface redox reaction of $\mathrm{Ni}^{2+}$ and $\mathrm{NiOOH}$, present in $\mathrm{NiV} \mathrm{LDH.}{ }^{63,64}$

$$
\mathrm{Ni}(\mathrm{OH})_{2}+\mathrm{OH}^{-} \leftrightarrow \mathrm{NiOOH}+\mathrm{H}_{2} \mathrm{O}+\mathrm{e}^{-}
$$

GCD curves for $\mathrm{Ni}_{0.80} \mathrm{~V}_{0.20} \mathrm{LDH}$ show that the shape of the charge-discharge curve was retained as the current density was 

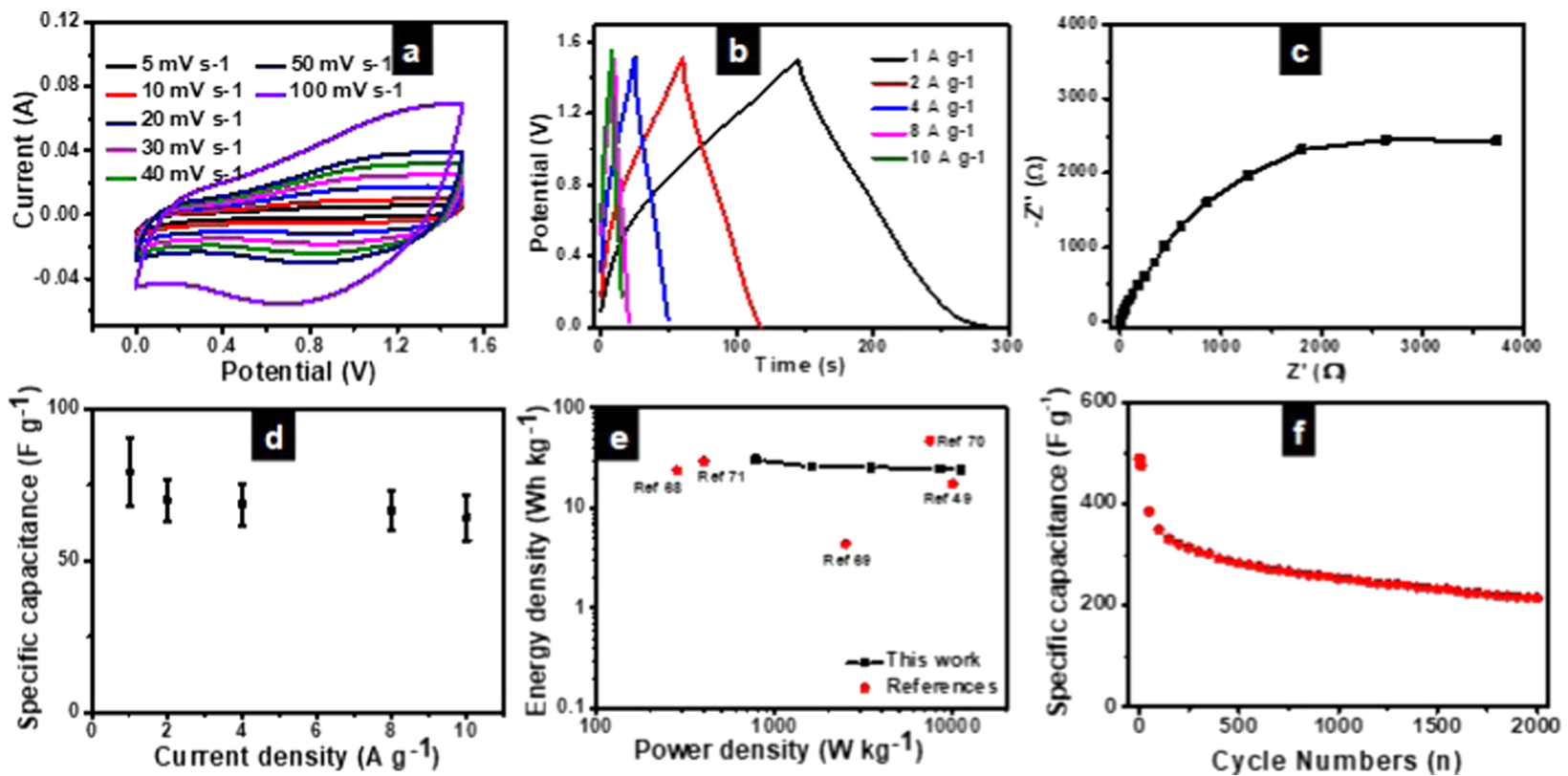

Figure 7. (a) CV curves for HSC at various scan rates. (b) GCD curves for HSC at various current densities. (c) EIS curve for HSC. (d) Specific capacitance variation with current density for HSC. (e) Ragone plot for HSC. (f) Retention of specific capacitance with number of cycles at current density of $1 \mathrm{~A} \mathrm{~g}^{-1}$ for HSC.

changed from 1 to $10 \mathrm{~A} \mathrm{~g}^{-1}$, confirming the high rate capability of NiV LDH material. The shape of the GCD curves also confirms the battery-like behavior of NiV LDH material. ${ }^{65}$ The maximum specific capacities of $\mathrm{Ni}_{0.80} \mathrm{~V}_{0.20} \mathrm{LDH}$ were found to be $711 \mathrm{C} \mathrm{g}^{-1}\left(1581 \mathrm{~F} \mathrm{~g}^{-1}\right), 622 \mathrm{C} \mathrm{g}^{-1}\left(1382 \mathrm{~F} \mathrm{~g}^{-1}\right), 580 \mathrm{C} \mathrm{g}^{-1}$ $\left(1289 \mathrm{~F} \mathrm{~g}^{-1}\right), 559 \mathrm{C} \mathrm{g}^{-1}\left(1242 \mathrm{~F} \mathrm{~g}^{-1}\right)$, and $549 \mathrm{C} \mathrm{g}^{-1}(1220 \mathrm{~F}$ $\left.\mathrm{g}^{-1}\right)$ at current densities of $1,2,4,8$, and $10 \mathrm{~A} \mathrm{~g}^{-1}$, respectively. Figure $6 \mathrm{f}$ shows the comparison of specific capacity retention and current density for $\mathrm{Ni}_{0.67} \mathrm{~V}_{0.33} \mathrm{LDH}, \mathrm{Ni}_{0.75} \mathrm{~V}_{0.25} \mathrm{LDH}$, and $\mathrm{Ni}_{0.80} \mathrm{~V}_{0.20}$ LDH using specific capacitance data for three different electrodes for each $\mathrm{NiV} \mathrm{LDH}$ material. The rate capability of $\mathrm{Ni}_{0.80} \mathrm{~V}_{0.20} \mathrm{LDH}(\sim 77 \%)$, as calculated from the GCD curves, was higher compared to $\mathrm{Ni}_{0.67} \mathrm{~V}_{0.33} \mathrm{LDH}(\sim 58 \%)$ and $\mathrm{Ni}_{0.75} \mathrm{~V}_{0.25} \mathrm{LDH}(\sim 35.5 \%)$ as the current density was increased from 1 to $10 \mathrm{~A} \mathrm{~g}^{-1}$. The $\mathrm{CV}$ and GCD curves for $\mathrm{Ni}_{0.67} \mathrm{~V}_{0.33} \mathrm{LDH}$ and $\mathrm{Ni}_{0.75} \mathrm{~V}_{0.25} \mathrm{LDH}$ are shown in Figure S7. Figures S8 and S9 show the electrochemical characterization for pure $\mathrm{Ni}$ hydroxide and $\mathrm{V}$ hydroxides, respectively, suggesting that $\mathrm{Ni}$ hydroxide has better redox behavior than $\mathrm{V}$-based hydroxides. Figure S10 presents the comparison of CV curves for $\mathrm{Ni}$ foam, $\mathrm{V}$-based hydroxide, $\mathrm{Ni}$ hydroxide, and $\mathrm{Ni}_{0.80} \mathrm{~V}_{0.20} \mathrm{LDH}$ at a scan rate of $5 \mathrm{mV} \mathrm{s}^{-1}$. The $\mathrm{CV}$ curves show that contribution of $\mathrm{Ni}$ foam is negligible and area under the curve is maximum for $\mathrm{Ni}_{0.80} \mathrm{~V}_{0.20} \mathrm{LDH}$. Table S3 exhibits comparative specific capacitances for the electrodes with active materials of pure $\mathrm{Ni}$ hydroxide, $\mathrm{V}$ hydroxide, $\mathrm{Ni}_{0.67} \mathrm{~V}_{0.33} \mathrm{LDH}$, $\mathrm{Ni}_{0.75} \mathrm{~V}_{0.25} \mathrm{LDH}$, and $\mathrm{Ni}_{0.80} \mathrm{~V}_{0.20} \mathrm{LDH}$ at different current densities, showing that $\mathrm{Ni}_{0.80} \mathrm{~V}_{0.20} \mathrm{LDHs}$ have higher specific capacitance. The average specific capacities (average of three electrodes) of pure $\mathrm{Ni}$ hydroxide, $\mathrm{V}$ hydroxide, $\mathrm{Ni}_{0.67} \mathrm{~V}_{0.33}$ $\mathrm{LDH}, \mathrm{Ni}_{0.75} \mathrm{~V}_{0.25} \mathrm{LDH}$, and $\mathrm{Ni}_{0.80} \mathrm{~V}_{0.20} \mathrm{LDH}$ were found to be $197 \mathrm{C} \mathrm{g}^{-1}\left(467 \mathrm{~F} \mathrm{~g}^{-1}\right), 60 \mathrm{C} \mathrm{g}^{-1}\left(144 \mathrm{~F} \mathrm{~g}^{-1}\right), 377 \mathrm{C} \mathrm{g}^{-1}$ $\left(839 \mathrm{~F} \mathrm{~g}^{-1}\right), 473 \mathrm{C} \mathrm{g}^{-1}\left(1104 \mathrm{~F} \mathrm{~g}^{-1}\right)$, and $603 \mathrm{C} \mathrm{g}^{-1}(1366 \mathrm{~F}$ $\left.\mathrm{g}^{-1}\right)$, respectively, at a current density of $1 \mathrm{~A} \mathrm{~g}^{-1}$. The EIS images of $\mathrm{Ni}_{0.67} \mathrm{~V}_{0.33} \mathrm{LDH}, \mathrm{Ni}_{0.75} \mathrm{~V}_{0.25} \mathrm{LDH}$, and $\mathrm{Ni}_{0.80} \mathrm{~V}_{0.20}$ LDH shown in Figure $S 11$ reveal the higher specific capacitance for $\mathrm{Ni}_{0.80} \mathrm{~V}_{0.20} \mathrm{LDH}$ compared to $\mathrm{Ni}_{0.67} \mathrm{~V}_{0.33} \mathrm{LDH}$ and $\mathrm{Ni}_{0.75} \mathrm{~V}_{0.25}$ LDH. It further infers that experimental data points well corroborated with the fitted data points (Figure $6 \mathrm{c})$. The overall resistance, i.e., combining electrolyte $\left(R_{\mathrm{s}}\right)$ and contact resistances, and resistance due to electroactive material, was found to be $4.54 \mathrm{k} \Omega$ for $\mathrm{Ni}_{0.80} \mathrm{~V}_{0.20} \mathrm{LDH}$. In addition, the charge-transfer resistance $\left(R_{\mathrm{ct}}\right)$ for $\mathrm{Ni}_{0.80} \mathrm{~V}_{0.20}$ $\mathrm{LDH}$ was found to be $883 \mathrm{~m} \Omega$ (Table S2). Hence, it can be inferred that the better supercapacitive performance of $\mathrm{Ni}_{0.80} \mathrm{~V}_{0.20} \mathrm{LDH}$ was due to its more exfoliated morphology across the layers, which helps in channelizing more electrolyte ions interaction with the electrode active surface and thus results in more redox reaction. ${ }^{66}$ The linear relationship between the peak current for anodic and cathodic peaks vs square root of scan rate, as shown in Figure 6d, confirms bulk intercalation of electrolyte ions into the surface of $\mathrm{Ni}_{0.80} \mathrm{~V}_{0.20}$ $\mathrm{LDH}$, which facilitates bulk redox reaction. ${ }^{26}$ Figure $6 \mathrm{e}$ presents the specific capacitance retention of $\mathrm{Ni}_{0.80} \mathrm{~V}_{0.20} \mathrm{LDH}$ with the number of cycles at a current density of $1 \mathrm{~A} \mathrm{~g}^{-1}$. It is noted from the cycling curves that the specific capacitance decreased up to $40 \%$ during the first 1000 cycles and then remained stable up to the next 10000 cycles. So, the initial capacitance decay is attributed to structure collapse, phase transformation, and reduction in active surface area. ${ }^{67}$ Columbic efficiency was found to be $100 \%$ up to 10000 cycles.

3.2. Hybrid Supercapacitor Testing. To further assess the electrochemical performance of $\mathrm{NiV} \mathrm{LDH}$ material, an HSC device was fabricated using $\mathrm{Ni}_{0.80} \mathrm{~V}_{0.20} \mathrm{LDH}$ as positive electrode and commercial activated carbon as negative electrode. $\mathrm{Ni}_{0.80} \mathrm{~V}_{0.20} \mathrm{LDH}$ was chosen due to its better supercapacitive performance in a three-electrode cell test, compared to other counterparts. Scheme 1 shows the fabrication of HSC device. Electrochemical results for commercial activated carbon are shown in Figure S12. Based on the GCD curves of activated carbon (Figure S12b) and $\mathrm{Ni}_{0.80} \mathrm{~V}_{0.20} \mathrm{LDH}$ (Figure $6 \mathrm{~b}$ ) at a current density of $1 \mathrm{~A} \mathrm{~g}^{-1}$, the values of average specific capacitance were found to be $205 \mathrm{~F}$ $\mathrm{g}^{-1}\left(C_{-}\right)$and $1366 \mathrm{~F} \mathrm{~g}^{-1}\left(C_{+}\right)$. The potential windows $\Delta V_{+}$ 
Table 1. Comparison of Energy Density and Power Density with Other Materials

\begin{tabular}{|c|c|c|c|c|}
\hline material & electrolyte & energy density $\left(\mathrm{Wh} \mathrm{kg}^{-1}\right)$ & power density $\left(\mathrm{W} \mathrm{kg}^{-1}\right)$ & ref \\
\hline \multirow{2}{*}{$\mathrm{Ni}(\mathrm{OH})_{2} /$ graphene } & $6 \mathrm{M} \mathrm{KOH}$ & 36.7 & $\sim 100$ & 74 \\
\hline & & $\sim 10.0$ & 7980 & \\
\hline \multirow[t]{2}{*}{ carbon/CoO nanoparticles } & $2 \mathrm{M} \mathrm{KOH}$ & 25.0 & 350 & 75 \\
\hline & & 17.4 & 7000 & \\
\hline \multirow[t]{2}{*}{$\mathrm{NiCo}_{2} \mathrm{~S}_{4} /$ bio-carbon } & $2 \mathrm{M} \mathrm{KOH}$ & 27.7 & $\sim 264$ & 76 \\
\hline & & 16.1 & 5000 & \\
\hline \multirow[t]{2}{*}{$\mathrm{NiCo}_{2} \mathrm{O}_{4} @ \mathrm{NiCo}_{2} \mathrm{~S}_{4} / \mathrm{Ni}$ foam } & $3 \mathrm{M} \mathrm{KOH}$ & 35.6 & 1500 & 77 \\
\hline & & 14.4 & 7500 & \\
\hline \multirow[t]{2}{*}{$\mathrm{NiO}-\mathrm{CuO}$ mesoporous nanowires } & $3 \mathrm{M} \mathrm{KOH}$ & 33.8 & 400 & 78 \\
\hline & & 18.4 & 8000 & \\
\hline \multirow{2}{*}{$\mathrm{Co}_{3} \mathrm{O}_{4} / \mathrm{N}$-doped carbon hollow spheres } & $2 \mathrm{M} \mathrm{KOH}$ & 34.5 & 753 & 79 \\
\hline & & 29.0 & 3807 & \\
\hline \multirow[t]{2}{*}{ CoS hollow structures } & $2 \mathrm{M} \mathrm{KOH}$ & 39.9 & 756 & 80 \\
\hline & & $\sim 20.0$ & 10000 & \\
\hline \multirow[t]{2}{*}{$\mathrm{Ni}_{0.80} \mathrm{~V}_{0.20} \mathrm{LDH}$} & $2 \mathrm{M} \mathrm{KOH}$ & 30.6 & 780 & this work \\
\hline & & 24.6 & 11100 & \\
\hline
\end{tabular}

and $\Delta V_{-}$are 0.45 and $-1 \mathrm{~V}$, respectively. According to eq 1 , the optimum ratio of $m_{-}$and $m_{+}$was found to be 2.78 . The CV curves of $\mathrm{Ni}_{0.80} \mathrm{~V}_{0.20} \mathrm{LDH}$ and commercial activated carbon were measured using a three-electrode system at a scan rate of $50 \mathrm{mV} \mathrm{s}^{-1}$ in $2 \mathrm{M} \mathrm{KOH}$ electrolyte and are plotted in Figure S13, which suggests the optimized operating potential window for HSC to be $1.5 \mathrm{~V}$. Figure $7 \mathrm{a}$ presents the CV curves of $\mathrm{Ni}_{0.80} \mathrm{~V}_{0.20} \mathrm{LDH} /$ activated carbon HSC at different scan rates from 5 to $100 \mathrm{mV} \mathrm{s}^{-1}$. The shape of the $\mathrm{CV}$ curves is almost rectangular with small redox peaks present in the anodic and cathodic parts of the curves, suggesting the pseudocapacitive behavior of HSC. There was no obvious distortion in the shape of $\mathrm{CV}$ curve even at different scan rates from 5 to $100 \mathrm{mV} \mathrm{s}^{-1}$, thus confirming the higher rate capability and fast chargedischarge properties of HSC. ${ }^{50}$ The GCD curves for $\mathrm{Ni}_{0.80} \mathrm{~V}_{0.20}$ $\mathrm{LDH} /$ activated carbon HSC are shown in Figure $7 \mathrm{~b}$. The shape of the GCD curves is triangular with small deviation in linear shape, confirming the pseudocapacitive charge storage of $\mathrm{Ni}_{0.80} \mathrm{~V}_{0.20} \mathrm{LDH} /$ activated carbon HSC. The shape of the GCD curves remained same even at higher current densities of 1-10 A $\mathrm{g}^{-1}$, suggesting the higher degree of electrochemical reversibility of redox process and good Columbic efficiency. ${ }^{37,51}$ The maximum specific capacitance values for the constructed HSC device were found to be 98, 83, 82, 79, and $77 \mathrm{~F} \mathrm{~g}^{-1}$ at current densities of $1,2,4,8$, and $10 \mathrm{~A} \mathrm{~g}^{-1}$, respectively. The variation of average specific capacitance of six such devices with current densities is shown in Figure $7 d$, confirming $\sim 79 \%$ retention in average specific capacitance at a higher current density of $10 \mathrm{~A} \mathrm{~g}^{-1} \cdot \mathrm{Ni}_{0.80} \mathrm{~V}_{0.20} \mathrm{LDH} /$ activated carbon HSC device in Figure $7 \mathrm{~b}$ shows a potential drop of 12 $\mathrm{mV}$ at $1 \mathrm{~A} \mathrm{~g}^{-1}$ current density, which was increased to $440 \mathrm{mV}$ at $10 \mathrm{~A} \mathrm{~g}^{-1}$ current density. The EIS curve of $\mathrm{Ni}_{0.80} \mathrm{~V}_{0.20} \mathrm{LDH} /$ activated carbon HSC device in Figure $7 \mathrm{c}$ shows a similar shape to NiV LDH. The Ragone plot for $\mathrm{Ni}_{0.80} \mathrm{~V}_{0.20} \mathrm{LDH} /$ activated carbon HSC device is shown in Figure 7e. The device showed an excellent energy density of $30.6 \mathrm{Wh} \mathrm{kg}^{-1}$ at a power density of $0.78 \mathrm{~kW} \mathrm{~kg}^{-1}$, which remained at $24 \mathrm{Wh} \mathrm{kg}^{-1}$ at a higher power density of $11.1 \mathrm{~kW} \mathrm{~kg}^{-1}$. A comparison of energy density and power density with other reported materials is reported in Table 1 . The cycling stability of $\mathrm{Ni}_{0.80} \mathrm{~V}_{0.20} \mathrm{LDH} /$ activated carbon HSC device is shown in Figure $7 \mathrm{f}^{51,68-71}$ The cycling study shows a rapid decrease in the specific capacitance for the first few ten cycles and then remained constant almost up to 2000 cycles. The specific capacitance was found to be $\sim 42 \%$ of the initial value after 2000 cycles. Moreover, $\mathrm{Ni}_{0.80} \mathrm{~V}_{0.20} \mathrm{LDH} /$ activated carbon HSC solid-state device with $\mathrm{LiCl} /$ poly(vinyl alcohol) gel electrolyte was successfully used to power a red light-emitting diode of $1.8 \mathrm{~V}$ for almost 2 min after charging with $8 \mathrm{~mA}$.

\section{CONCLUSIONS}

In summary, we have successfully demonstrated a facile and cost-effective hydrothermal method for the synthesis of $\mathrm{NiV}$ LDH having controlled composition. Electrochemical studies showed that $\mathrm{Ni}_{0.80} \mathrm{~V}_{0.20} \mathrm{LDH}$ shows better supercapacitive behavior than $\mathrm{Ni}_{0.67} \mathrm{~V}_{0.33} \mathrm{LDH}$ and $\mathrm{Ni}_{0.75} \mathrm{~V}_{0.25} \mathrm{LDH}$ due to its $3 \mathrm{D}$ exfoliated morphology. $\mathrm{Ni}_{0.80} \mathrm{~V}_{0.20} \mathrm{LDH}$ showed a maximum specific capacity of $711 \mathrm{C} \mathrm{g}^{-1}\left(1581 \mathrm{~F} \mathrm{~g}^{-1}\right)$ at a current density of $1 \mathrm{~A} \mathrm{~g}^{-1}$, which remained at $549 \mathrm{C} \mathrm{g}^{-1}$ (1220 $\mathrm{F} \mathrm{g}^{-1}$ ) at a higher current density of $10 \mathrm{~A} \mathrm{~g}^{-1}$. The HSC device based on $\mathrm{Ni}_{0.80} \mathrm{~V}_{0.20} \mathrm{LDH} /$ activated carbon showed a maximum specific capacitance of $98 \mathrm{~F} \mathrm{~g}^{-1}$ at a current density of $1 \mathrm{~A} \mathrm{~g}^{-1}$ with retention of $\sim 79 \%\left(77 \mathrm{~F} \mathrm{~g}^{-1}\right)$ at a current density of $10 \mathrm{~A} \mathrm{~g}^{-1}$. The energy density was found to be 30.6 Wh kg-1 at a power density of $0.78 \mathrm{~kW} \mathrm{~kg}^{-1}$, which remained at $24 \mathrm{Wh} \mathrm{kg}^{-1}$ at a high power density of $11.1 \mathrm{~kW} \mathrm{~kg}^{-1}$. These results suggest that $\mathrm{NiV} \mathrm{LDH} \mathrm{nanostructures} \mathrm{have} \mathrm{significant}$ potential as low-cost electrode material for the energy-storage devices.

\section{EXPERIMENTAL SECTION}

5.1. Materials. Nickel chloride $\left(\mathrm{NiCl}_{2}\right)$ (98\%), vanadium chloride $\left(\mathrm{VCl}_{3}\right)(97 \%)$, potassium hydroxide $(\mathrm{KOH})$, and poly(vinylidene fluoride) (PVDF, average $\mathrm{MW}=534000)$ were purchased from Sigma-Aldrich, India. Urea (99\%), ethanol, $N$-methyl-2-pyrrolidone (NMP), and potassium hydroxide pellets were purchased from Merck, India. Conducting carbon black (Super P), activated carbon, and $\mathrm{Ni}$ foam were supplied from MTI Corporation.

5.2. Synthesis of NiV LDH Nanosheets. NiV LDH nanosheets were prepared through a one-step hydrothermal method. In a typical synthesis, various mole ratios of $\mathrm{Ni} / \mathrm{V}$ (2:1, 3:1, and 4:1 for the synthesis of $\mathrm{Ni}_{0.67} \mathrm{~V}_{0.33} \mathrm{LDH}$, $\mathrm{Ni}_{0.75} \mathrm{~V}_{0.25} \mathrm{LDH}$, and $\mathrm{Ni}_{0.80} \mathrm{~V}_{0.20} \mathrm{LDH}$, respectively) were taken in such a way that the amount of total ion concentration $\left(\mathrm{Ni}^{2+}\right.$ and $\mathrm{V}^{3+}$ ) remains $3.2 \mathrm{mmol}$. In brief, different ratios of $\mathrm{NiCl}_{2}$ 
and $\mathrm{VCl}_{3}$ and $0.3 \mathrm{~g}$ of urea were mixed in $40 \mathrm{~mL}$ of deionized (DI) water and stirred for $30 \mathrm{~min}$ to obtain a homogeneous solution. Then, the solution mixture was transferred to a Teflon-lined stainless steel autoclave and the reaction was performed at $120{ }^{\circ} \mathrm{C}$ for $12 \mathrm{~h}$. After cooling down the autoclave to room temperature, the obtained powder was washed with DI water and ethanol. NiV LDH nanosheets were collected after drying the resultant powder at $60{ }^{\circ} \mathrm{C}$ in a vacuum oven overnight. ${ }^{72}$ For comparison, pure $\mathrm{Ni}$ and $\mathrm{V}$ hydroxides were also prepared following the similar procedure.

5.3. Material Characterization. The surface morphologies of the as-synthesized LDHs were observed by field emission scanning electron microscopy (FESEM, Quanta 200, Zeiss, Germany). Transmission electron microscopy (FEI Titan G2 60-300 TEM (HRTEM)) was further used to observe the morphology, size, and composition of the assynthesized LDHs. The crystal structures of various LDH materials were analyzed through X-ray diffraction (XRD) patterns obtained from an X-ray diffractometer (X'Pert Pro, PANanalytical, the Netherlands). $\mathrm{Cu} \mathrm{K} \alpha(\lambda=1.5406 \AA)$ was used to obtain the XRD patterns. Fourier transform infrared (FTIR, PerkinElmer) spectroscopy using $\mathrm{KBr}$ pellet method was used to study the presence of functional groups in $\mathrm{NiV}$ LDHs. X-ray photoelectron spectroscopy (XPS) measurements were carried out using a PHI 5000 Versa Probe II, FEI Inc. spectrometer. XPS binding energy values for all of the samples were referenced to $\mathrm{C} 1 \mathrm{~s}$ hydrocarbon peak at $284.6 \mathrm{eV}$. The Brunauer-Emmett-Teller (BET) surface area and BarrettJoyner-Halenda (BJH) pore size distribution of the assynthesized LDHs were measured through the $\mathrm{N}_{2}$ adsorptiondesorption method (Quantachrome Instruments).

5.4. Electrochemical Characterization. $\mathrm{NiV}$ LDH, PVDF, and super $P$ were mixed in a weight ratio of 75:15:10 in NMP solvent to make a homogeneous slurry. Ni foam $(1 \mathrm{~cm}$ $\times 3 \mathrm{~cm}$ ) pieces were coated on a $1 \mathrm{~cm} \times 1 \mathrm{~cm}$ area using this slurry and dried at $80{ }^{\circ} \mathrm{C}$ for $12 \mathrm{~h}$ to make the working electrodes. Pure Ni and pure V hydroxide electrodes were also prepared following the similar procedure. The material loading was kept in the range of $2-3 \mathrm{mg}$ for all electrodes. A threeelectrode electrochemical set up was used to study the supercapacitive performance of $\mathrm{NiV} \mathrm{LDH}$ material. The three-electrode assembly consists of $\mathrm{NiV} \mathrm{LDH}$-coated $\mathrm{Ni}$ foam as the working electrode, $\mathrm{Ag} / \mathrm{AgCl} / \mathrm{KCl}, \mathrm{Pt}$ rod as the reference electrode and counter electrode, and $2 \mathrm{M} \mathrm{KOH}$ as the electrolyte, respectively.

HSC devices were fabricated using NiV LDH materials and activated carbon as positive and negative electrodes, respectively. To maintain the charge on positive $\left(q_{+}\right)$and negative $\left(q_{-}\right)$electrodes, i.e., $q_{+} \approx q_{-}$, the ratio of positive $\left(m_{+}\right)$ to negative $\left(m_{-}\right)$electrodes was maintained according to the following equation

$$
\frac{m_{-}}{m_{+}}=\frac{C_{+} \times \Delta V_{+}}{C_{-} \times \Delta V_{-}}
$$

where $C_{+}$and $C_{-}$are the specific capacitances of positive and negative electrodes, respectively, and $\Delta V_{+}$and $\Delta V_{-}$are the potential windows for the GCD process of positive and negative electrodes, respectively. ${ }^{26}$ The optimum ratio was found to be 2.78 based on the specific capacitance values for positive and negative electrodes at $1 \mathrm{~A} \mathrm{~g}^{-1}$. The electrochemical performance of $\mathrm{NiV} \mathrm{LDH}$ and HSC was studied using potentiostat/galvanostat (Autolab $302 \mathrm{~N}$, Metrohm, the
Netherlands). Galvanostatic charge-discharge (GCD), cyclic voltammetry $(\mathrm{CV})$, and electrochemical impedance spectroscopy (EIS) studies were conducted at the open-circuit voltage over a frequency range of $0.01 \mathrm{~Hz}-100 \mathrm{kHz}$. The specific capacitance $\left(C_{s}\right)$ of active material was calculated through GCD curves using the following equations ${ }^{73}$

$$
\begin{aligned}
& C_{\mathrm{s}}=\frac{I \Delta t}{m \Delta V}\left(\text { specific capacitance, } \mathrm{Fg}^{-1}\right) \\
& C=\frac{I \Delta t}{m}\left(\text { specific capacity, } \mathrm{C} \mathrm{g}^{-1}\right) \\
& C_{\mathrm{s}}=\frac{I \Delta t}{M \Delta V}\left(\text { specific capacitance of HSC device, } \mathrm{Fg}^{-1}\right)
\end{aligned}
$$

where $I$ is the current $(\mathrm{A}), m$ is the mass of active material $(\mathrm{g})$ in the three-electrode system, $M$ is the total mass of active materials at positive and negative electrodes in HSC, $\Delta t$ is the discharging time (s), and $\Delta V$ is the applied potential window $(\mathrm{V})$. The energy density $\left(E, \mathrm{Wh} \mathrm{kg}^{-1}\right)$ and power density $(P$, $\mathrm{W} \mathrm{kg}^{-1}$ ) of HSC were calculated using the following equations

$$
\begin{aligned}
& E=\frac{1}{2} C_{s} V^{2} \\
& P=\frac{E}{\Delta t}
\end{aligned}
$$

\section{ASSOCIATED CONTENT}

\section{Supporting Information}

The Supporting Information is available free of charge on the ACS Publications website at DOI: 10.1021/acsomega.8b03618.

XRD and FESEM for Ni and $\mathrm{V}$ hydroxide; BET and XPS data for $\mathrm{Ni}_{0.67} \mathrm{~V}_{0.33}$ and $\mathrm{Ni}_{0.75} \mathrm{~V}_{0.25} \mathrm{LDH}$; electrochemical data for $\mathrm{Ni} / \mathrm{V}$ hydroxide and $\mathrm{Ni}_{0.67} \mathrm{~V}_{0.33} /$ $\mathrm{Ni}_{0.75} \mathrm{~V}_{0.25} \mathrm{LDH}$; and EIS data for $\mathrm{Ni}_{0.67} \mathrm{~V}_{0.33} \mathrm{LDH}$, $\mathrm{Ni}_{0.75} \mathrm{~V}_{0.25} \mathrm{LDH}$ and $\mathrm{Ni}_{0.80} \mathrm{~V}_{0.20}$ LDH (PDF)

\section{AUTHOR INFORMATION}

\section{Corresponding Author}

*E-mail: guptark@iitk.ac.in. Tel: +91-5122596972. Fax: +915122590104.

ORCID $\odot$

Vijay Kumar Thakur: 0000-0002-0790-2264

Raju Kumar Gupta: 0000-0002-5537-8057

\section{Notes}

The authors declare no competing financial interest.

\section{ACKNOWLEDGMENTS}

R.K.G. acknowledges financial support from Department of Science and Technology (DST), India, through the INSPIRE Faculty Award (Project No. IFA-13 ENG-57) and Grant No. DST/TMD/CERI/C140(G).

\section{REFERENCES}

(1) Conway, B. E. Electrochemical Supercapacitors: Scientific Fundamentals and Technological Applications; Springer, 2013.

(2) Simon, P.; Gogotsi, Y. Materials for electrochemical capacitors. Nat. Mater. 2008, 7, 845-854. 
(3) Wang, G.; Zhang, L.; Zhang, J. A review of electrode materials for electrochemical supercapacitors. Chem. Soc. Rev. 2012, 41, 797828.

(4) Tyagi, A.; Tripathi, K. M.; Gupta, R. K. Recent progress in micro-scale energy storage devices and future aspects. J. Mater. Chem. A 2015, 3, 22507-22541.

(5) Winter, M.; Brodd, R. J. What are batteries, fuel cells, and supercapacitors? Chem. Rev. 2004, 104, 4245-4270.

(6) Kötz, R; Carlen, M. Principles and applications of electrochemical capacitors. Electrochim. Acta 2000, 45, 2483-2498.

(7) Liu, C.; Li, F.; Ma, L.-P.; Cheng, H.-M. Advanced materials for energy storage. Adv. Mater. 2010, 22, E28-E62.

(8) Burke, A. Ultracapacitors: Why, how, and where is the technology. J. Power Sources 2000, 91, 37-50.

(9) Meher, S. K.; Rao, G. R. Ultralayered $\mathrm{Co}_{3} \mathrm{O}_{4}$ for highperformance supercapacitor applications. J. Phys. Chem. C 2011, $115,15646-15654$

(10) Wei, W.; Cui, X.; Chen, W.; Ivey, D. G. Manganese oxide-based materials as electrochemical supercapacitor electrodes. Chem. Soc. Rev. 2011, 40, 1697-1721.

(11) Sugimoto, W.; Yokoshima, K.; Murakami, Y.; Takasu, Y. Charge storage mechanism of nanostructured anhydrous and hydrous ruthenium-based oxides. Electrochim. Acta 2006, 52, 1742-1748.

(12) Zhang, J.; Wang, Y.; Wu, J.; Shu, X.; Yu, C.; Cui, J.; Qin, Y.; Zhang, Y.; Ajayan, P. M.; Wu, Y. Remarkable supercapacitive performance of $\mathrm{TiO}_{2}$ nanotube arrays by introduction of oxygen vacancies. Chem. Eng. J. 2017, 313, 1071-1081.

(13) Yang, Z.; Xu, F.; Zhang, W.; Mei, Z.; Pei, B.; Zhu, X. Controllable preparation of multishelled $\mathrm{NiO}$ hollow nanospheres via layer-by-layer self-assembly for supercapacitor application. J. Power Sources 2014, 246, 24-31.

(14) Zhang, M.; Sha, J.; Miao, X.; Liu, E.; Shi, C.; Li, J.; He, C.; Li, Q.; Zhao, N. Three-dimensional graphene anchored $\mathrm{Fe}_{2} \mathrm{O}_{3} @ \mathrm{C}$ coreshell nanoparticles as supercapacitor electrodes. J. Alloys Compd. 2017, 696, 956-963.

(15) Kong, L.; Zhang, C.; Wang, J.; Qiao, W.; Ling, L.; Long, D. Nanoarchitectured $\mathrm{Nb}_{2} \mathrm{O}_{5}$ hollow, $\mathrm{Nb}_{2} \mathrm{O}_{5} @$ carbon and $\mathrm{NbO}_{2} @$ carbon core-shell microspheres for ultrahigh-rate intercalation pseudocapacitors. Sci. Rep. 2016, 6, No. 21177.

(16) Shown, I.; Ganguly, A.; Chen, L.-C.; Chen, K.-H. Conducting polymer-based flexible supercapacitor. Energy Sci. Eng. 2015, 3, 2-26.

(17) Kim, J.; Lee, J.; You, J.; Park, M.-S.; Hossain, M. S. A.; Yamauchi, Y.; Kim, J. H. Conductive polymers for next-generation energy storage systems: Recent progress and new functions. Mater. Horiz. 2016, 3, 517-535.

(18) Wang, R.; Lang, J.; Liu, Y.; Lin, Z.; Yan, X. Ultra-small, sizecontrolled $\mathrm{Ni}(\mathrm{OH})_{2}$ nanoparticles: Elucidating the relationship between particle size and electrochemical performance for advanced energy storage devices. NPG Asia Mater. 2015, 7, No. e183.

(19) Liu, Y.; Wang, R.; Yan, X. Synergistic effect between ultra-small nickel hydroxide nanoparticles and reduced graphene oxide sheets for the application in high-performance asymmetric supercapacitor. Sci. Rep. 2015, 5, No. 11095

(20) Zhang, G.; Lou, X. W. General solution growth of mesoporous $\mathrm{NiCo}_{2} \mathrm{O}_{4}$ nanosheets on various conductive substrates as highperformance electrodes for supercapacitors. Adv. Mater. 2013, 25, 976-979.

(21) Zhang, G.; Lou, X. W. Controlled growth of $\mathrm{NiCo}_{2} \mathrm{O}_{4}$ nanorods and ultrathin nanosheets on carbon nanofibers for high-performance supercapacitors. Sci. Rep. 2013, 3, No. 1470.

(22) Wang, Z.; Jia, W.; Jiang, M.; Chen, C.; Li, Y. One-step accurate synthesis of shell controllable $\mathrm{CoFe}_{2} \mathrm{O}_{4}$ hollow microspheres as highperformance electrode materials in supercapacitor. Nano Res. 2016, 9, 2026-2033.

(23) Zhang, M.; Guo, S.; Zheng, L.; Zhang, G.; Hao, Z.; Kang, L.; $\mathrm{Liu}, \mathrm{Z}$.-H. Preparation of $\mathrm{NiMn}_{2} \mathrm{O}_{4}$ with large specific surface area from an epoxide-driven sol-gel process and its capacitance. Electrochim. Acta 2013, 87, 546-553.
(24) Tholkappiyan, R.; Naveen, A. N.; Sumithra, S.; Vishista, K. Investigation on spinel $\mathrm{MnCo}_{2} \mathrm{O}_{4}$ electrode material prepared via controlled and uncontrolled synthesis route for supercapacitor application. J. Mater. Sci. 2015, 50, 5833-5843.

(25) Jadhav, H. S.; Pawar, S. M.; Jadhav, A. H.; Thorat, G. M.; Seo, J. G. Hierarchical mesoporous 3D flower-like $\mathrm{CuCo}_{2} \mathrm{O}_{4} / \mathrm{NF}$ for highperformance electrochemical energy storage. Sci. Rep. 2016, 6, No. 31120.

(26) Chen, H.; Chang, X.; Chen, D.; Liu, J.; Liu, P.; Xue, Y.; Lin, H.; $\mathrm{Han}, \mathrm{S}$. Graphene-karst cave flower-like $\mathrm{Ni}-\mathrm{Mn}$ layered double oxides nanoarrays with energy storage electrode. Electrochim. Acta 2016, 220, 36-46.

(27) Daud, M.; Kamal, M. S.; Shehzad, F.; Al-Harthi, M. A. Graphene/layered double hydroxides nanocomposites: A review of recent progress in synthesis and applications. Carbon 2016, 104, 241252

(28) Shao, M.; Zhang, R.; Li, Z.; Wei, M.; Evans, D. G.; Duan, X. Layered double hydroxides toward electrochemical energy storage and conversion: Design, synthesis and applications. Chem. Commun. 2015, 51, 15880-15893.

(29) Sarfraz, M.; Shakir, I. Recent advances in layered double hydroxides as electrode materials for high-performance electrochemical energy storage devices. J. Energy Storage 2017, 13, 103-122.

(30) ten Elshof, J. E.; Yuan, H.; Gonzalez Rodriguez, P. Twodimensional metal oxide and metal hydroxide nanosheets: Synthesis, controlled assembly and applications in energy conversion and storage. Adv. Energy Mater. 2016, 6, No. 1600355

(31) Wang, Q.; O'Hare, D. Recent advances in the synthesis and application of layered double hydroxide (LDH) nanosheets. Chem. Rev. 2012, 112, 4124-4155.

(32) Zhao, M.; Zhao, Q.; Li, B.; Xue, H.; Pang, H.; Chen, C. Recent progress in layered double hydroxide based materials for electrochemical capacitors: Design, synthesis and performance. Nanoscale 2017, 9, 15206-15225.

(33) Zhang, L.; Hui, K. N.; San Hui, K.; Lee, H. High-performance hybrid supercapacitor with 3D hierarchical porous flower-like layered double hydroxide grown on nickel foam as binder-free electrode. $J$. Power Sources 2016, 318, 76-85.

(34) Brousse, T.; Bélanger, D.; Long, J. W. To be or not to be pseudocapacitive? J. Electrochem. Soc. 2015, 162, A5185-A5189.

(35) Pu, J.; Tong, Y.; Wang, S.; Sheng, E.; Wang, Z. Nickel-cobalt hydroxide nanosheets arrays on $\mathrm{Ni}$ foam for pseudocapacitor applications. J. Power Sources 2014, 250, 250-256.

(36) Lv, Z.; Zhong, Q.; Bu, Y. Controllable synthesis of Ni-Co nanosheets covered hollow box via altering the concentration of nitrate for high performance supercapacitor. Electrochim. Acta 2016, $215,500-505$.

(37) Xu, J.; Ju, Z.; Cao, J.; Wang, W.; Wang, C.; Chen, Z. Microwave synthesis of nitrogen-doped mesoporous carbon/nickel-cobalt hydroxide microspheres for high-performance supercapacitors. J. Alloys Compd. 2016, 689, 489-499.

(38) Wang, T.; Zhang, S.; Yan, X.; Lyu, M.; Wang, L.; Bell, J.; Wang, H. 2-Methylimidazole-derived $\mathrm{Ni}-\mathrm{Co}$ layered double hydroxide nanosheets as high rate capability and high energy density storage material in hybrid supercapacitors. ACS Appl. Mater. Interfaces 2017, 9, 15510-15524.

(39) Zhang, L.; Hui, K. N.; Hui, K. S.; Lee, H. Facile synthesis of porous CoAl-layered double hydroxide/graphene composite with enhanced capacitive performance for supercapacitors. Electrochim. Acta 2015, 186, 522-529.

(40) Bai, C.; Sun, S.; Xu, Y.; Yu, R.; Li, H. Facile one-step synthesis of nanocomposite based on carbon nanotubes and nickel-aluminum layered double hydroxides with high cycling stability for supercapacitors. J. Colloid Interface Sci. 2016, 480, 57-62.

(41) Li, X.; Zai, J.; Liu, Y.; He, X.; Xiang, S.; Ma, Z.; Qian, X. Atomically thin layered $\mathrm{NiFe}$ double hydroxides assembled $3 \mathrm{D}$ microspheres with promoted electrochemical performances. J. Power Sources 2016, 325, 675-681. 
(42) Lv, L.; Xu, K.; Wang, C.; Wan, H.; Ruan, Y.; Liu, J.; Zou, R.; Miao, L.; Ostrikov, K.; Lan, Y.; Jiang, J. Intercalation of glucose in NiMn-layered double hydroxide nanosheets: An effective path way towards battery-type electrodes with enhanced performance. Electrochim. Acta 2016, 216, 35-43.

(43) Hatui, G.; Nayak, G. C.; Udayabhanu, G. One pot solvothermal synthesis of sandwich-like $\mathrm{Mg} \mathrm{Al}$ layered double hydroxide anchored reduced graphene oxide: An excellent electrode material for supercapacitor. Electrochim. Acta 2016, 219, 214-226.

(44) Singh, D.; Choudhary, A.; Garg, A. Flexible and robust piezoelectric polymer nanocomposites based energy harvesters. ACS Appl. Mater. Interfaces 2018, 10, 2793-2800.

(45) Zhang, L.; Zhang, X.; Shen, L.; Gao, B.; Hao, L.; Lu, X.; Zhang, F.; Ding, B.; Yuan, C. Enhanced high-current capacitive behavior of graphene/CoAl-layered double hydroxide composites as electrode material for supercapacitors. J. Power Sources 2012, 199, 395-401.

(46) Tao, Y.; Ruiyi, L.; Tingting, Y.; Zaijun, L. Nickel/cobalt layered double hydroxide hollow microspheres with hydrangea-like morphology for high-performance supercapacitors. Electrochim. Acta 2015, 152, 530-537.

(47) Li, M.; Ma, K. Y.; Cheng, J. P.; Lv, D.; Zhang, X. B. Nickelcobalt hydroxide nanoflakes conformal coating on carbon nanotubes as a supercapacitive material with high-rate capability. J. Power Sources 2015, 286, 438-444.

(48) Tang, Y.; Liu, Y.; Yu, S.; Guo, W.; Mu, S.; Wang, H.; Zhao, Y.; Hou, L.; Fan, Y.; Gao, F. Template-free hydrothermal synthesis of nickel cobalt hydroxide nanoflowers with high performance for asymmetric supercapacitor. Electrochim. Acta 2015, 161, 279-289.

(49) Li, R.; Hu, Z.; Shao, X.; Cheng, P.; Li, S.; Yu, W.; Lin, W.; Yuan, D. Large scale synthesis of NiCo layered double hydroxides for superior asymmetric electrochemical capacitor. Sci. Rep. 2016, 6, No. 18737.

(50) Lin, W.; Yu, W.; Hu, Z.; Ouyang, W.; Shao, X.; Li, R.; Yuan, D. $\mathrm{S}$. Superior performance asymmetric supercapacitors based on flakelike $\mathrm{Co} / \mathrm{Al}$ hydrotalcite and graphene. Electrochim. Acta 2014, 143, 331-339.

(51) Li, X.; Zhang, Y.; Xing, W.; Li, L.; Xue, Q.; Yan, Z. Sandwichlike graphene/polypyrrole/layered double hydroxide nanowires for high-performance supercapacitors. J. Power Sources 2016, 331, 67-75.

(52) Zhang, F.; Zhang, C.; Zeng, R.; Song, L.; Guo, L.; Huang, X. Corrosion resistance of the superhydrophobic $\mathrm{Mg}(\mathrm{OH})_{2} / \mathrm{Mg}-\mathrm{Al}$ layered double hydroxide coatings on magnesium alloys. Metals 2016, 6, 85 .

(53) Hsieh, Z.-L.; Lin, M.-C.; Uan, J.-Y. Rapid direct growth of Li-Al layered double hydroxide (LDH) film on glass, silicon wafer and carbon cloth and characterization of LDH film on substrates. J. Mater. Chem. 2011, 21, 1880-1889.

(54) Masikhwa, T. M.; Madito, M. J.; Momodu, D. Y.; Dangbegnon, J. K.; Guellati, O.; Harat, A.; Guerioune, M.; Barzegar, F.; Manyala, N. High performance asymmetric supercapacitor based on CoAl-LDH/ GF and activated carbon from expanded graphite. RSC Adv. 2016, 6, 46723-46732.

(55) Tan, Za.; Zhang, W.; Qian, D.; Cui, C.; Xu, Q.; Li, L.; Li, S.; Li, Y. Solution-processed nickel acetate as hole collection layer for polymer solar cells. Phys. Chem. Chem. Phys. 2012, 14, 14217-14223.

(56) De Jesus, J. C.; González, I.; Quevedo, A.; Puerta, T. Thermal decomposition of nickel acetate tetrahydrate: An integrated study by TGA, QMS and XPS techniques. J. Mol. Catal. A: Chem. 2005, 228, 283-291.

(57) Mansour, A. N. Characterization of NiO by XPS. Surf. Sci. Spectra 1994, 3, 231-238.

(58) Biesinger, M. C.; Payne, B. P.; Grosvenor, A. P.; Lau, L. W. M.; Gerson, A. R.; Smart, R. S. C. Resolving surface chemical states in XPS analysis of first row transition metals, oxides and hydroxides: $\mathrm{Cr}$, $\mathrm{Mn}, \mathrm{Fe}, \mathrm{Co}$ and Ni. Appl. Surf. Sci. 2011, 257, 2717-2730.

(59) Biesinger, M. C.; Lau, L. W. M.; Gerson, A. R.; Smart, R. S. C. Resolving surface chemical states in XPS analysis of first row transition metals, oxides and hydroxides: $\mathrm{Sc}, \mathrm{Ti}, \mathrm{V}, \mathrm{Cu}$ and $\mathrm{Zn}$. Appl. Surf. Sci. 2010, 257, 887-898.
(60) Silversmit, G.; Depla, D.; Poelman, H.; Marin, G. B.; De Gryse, R. Determination of the V2p XPS binding energies for different vanadium oxidation states $\left(\mathrm{V}^{5+}\right.$ to $\left.\mathrm{V}^{0+}\right)$. J. Electron Spectrosc. Relat. Phenom. 2004, 135, 167-175.

(61) Chen, H.; Deng, Y.; Yu, Z.; Zhao, H.; Yao, Q.; Zou, X.; Bäckvall, J.-E.; Sun, J. 3D open-framework vanadoborate as a highly effective heterogeneous pre-catalyst for the oxidation of alkylbenzenes. Chem. Mater. 2013, 25, 5031-5036.

(62) Hu, Z.-A.; Xie, Y.-L.; Wang, Y.-X.; Wu, H.-Y.; Yang, Y.-Y.; Zhang, Z.-Y. Synthesis and electrochemical characterization of mesoporous $\mathrm{Co}_{\mathrm{x}} \mathrm{Ni}_{1-\mathrm{x}}$ layered double hydroxides as electrode materials for supercapacitors. Electrochim. Acta 2009, 54, 2737-2741.

(63) Caravaggio, G. A.; Detellier, C.; Wronski, Z. Synthesis, stability and electrochemical properties of $\mathrm{NiAl}$ and $\mathrm{NiV}$ layered double hydroxides. J. Mater. Chem. 2001, 11, 912-921.

(64) Park, H. W.; Chae, J. S.; Park, S.-M.; Kim, K.-B.; Roh, K. C. Nickel-based layered double hydroxide from guest vanadium oxide anions. Met. Mater. Int. 2013, 19, 887-894.

(65) Zhao, J.; Chen, J.; Xu, S.; Shao, M.; Zhang, Q.; Wei, F.; Ma, J.; Wei, M.; Evans, D. G.; Duan, X. Hierarchical NiMn layered double hydroxide/carbon nanotubes architecture with superb energy density for flexible supercapacitors. Adv. Funct. Mater. 2014, 24, 2938-2946.

(66) Teh, P. F.; Sharma, Y.; Pramana, S. S.; Srinivasan, M. Nanoweb anodes composed of one-dimensional, high aspect ratio, size tunable electrospun $\mathrm{ZnFe}_{2} \mathrm{O}_{4}$ nanofibers for lithium ion batteries. J. Mater. Chem. 2011, 21, 14999-15008.

(67) Li, M.; Cheng, J. P.; Wang, J.; Liu, F.; Zhang, X. B. The growth of nickel-manganese and cobalt-manganese layered double hydroxides on reduced graphene oxide for supercapacitor. Electrochim. Acta 2016, 206, 108-115.

(68) Wang, X.; Sumboja, A.; Lin, M.; Yan, J.; Lee, P. S. Enhancing electrochemical reaction sites in nickel-cobalt layered double hydroxides on zinc tin oxide nanowires: A hybrid material for an asymmetric supercapacitor device. Nanoscale 2012, 4, 7266-7272.

(69) Jagadale, A. D.; Guan, G.; Li, X.; Du, X.; Ma, X.; Hao, X.; Abudula, A. Ultrathin nanoflakes of cobalt-manganese layered double hydroxide with high reversibility for asymmetric supercapacitor. $J$. Power Sources 2016, 306, 526-534.

(70) Lee, I.; Jeong, G. H.; An, S.; Kim, S.-W.; Yoon, S. Facile synthesis of 3D MnNi-layered double hydroxides (LDH)/graphene composites from directly graphites for pseudocapacitor and their electrochemical analysis. Appl. Surf. Sci. 2018, 429, 196-202.

(71) Huang, L.; Liu, B.; Hou, H.; Wu, L.; Zhu, X.; Hu, J.; Yang, J. Facile preparation of flower-like NiMn layered double hydroxide/ reduced graphene oxide microsphere composite for high-performance asymmetric supercapacitors. J. Alloys Compd. 2018, 730, 71-80.

(72) Fan, K.; Chen, H.; Ji, Y.; Huang, H.; Claesson, P. M.; Daniel, Q.; Philippe, B.; Rensmo, H.; Li, F.; Luo, Y.; Sun, L. Nickelvanadium monolayer double hydroxide for efficient electrochemical water oxidation. Nat. Commun. 2016, 7, No. 11981.

(73) Zhang, J.; Zhao, X. S. On the configuration of supercapacitors for maximizing electrochemical performance. ChemSusChem 2012, 5, $818-841$.

(74) Shen, P.; Zhang, H.; Zhang, S.; Fei, L. Fabrication of completely interface-engineered $\mathrm{Ni}(\mathrm{OH})_{2} / \mathrm{rGO}$ nanoarchitectures for high-performance asymmetric supercapacitors. Appl. Surf. Sci. 2018, 460, 65-73.

(75) Long, J. Y.; Yan, Z. S.; Gong, Y.; Lin, J. H. MOF-derived Cl/Odoped $\mathrm{C} / \mathrm{CoO}$ and $\mathrm{C}$ nanoparticles for high performance supercapacitor. Appl. Surf. Sci. 2018, 448, 50-63.

(76) Wang, N.; Wang, Y.; Cui, S.; Hou, H.; Mi, L.; Chen, W. A hollow tube-on-tube architecture of carbon-tube-supported nickel cobalt sulfide nanotubes for advanced supercapacitors. ChemNanoMat 2017, 3, 269-276.

(77) Rong, H.; Chen, T.; Shi, R.; Zhang, Y.; Wang, Z. Hierarchical $\mathrm{NiCo}_{2} \mathrm{O}_{4} @ \mathrm{NiCo}_{2} \mathrm{~S}_{4}$ nanocomposite on $\mathrm{Ni}$ foam as an electrode for hybrid supercapacitors. ACS Omega 2018, 3, 5634-5642.

(78) Fang, Z.; Rehman, Su.; Sun, M.; Yuan, Y.; Jin, S.; Bi, H. Hybrid $\mathrm{NiO}-\mathrm{CuO}$ mesoporous nanowire array with abundant oxygen 
vacancies and a hollow structure as a high-performance asymmetric supercapacitor. J. Mater. Chem. A 2018, 6, 21131-21142.

(79) Liu, T.; Zhang, L.; You, W.; Yu, J. Core-shell nitrogen-doped carbon hollow spheres $/ \mathrm{Co}_{3} \mathrm{O}_{4}$ nanosheets as advanced electrode for high-performance supercapacitor. Small 2018, 14, No. 1702407.

(80) Hu, H.; Guan, B.; Lou, X. W. Construction of complex CoS hollow structures with enhanced electrochemical properties for hybrid supercapacitors. Chem 2016, 1, 102-113. 
2019-02-14

Hydrothermally tailored

three-dimensional Ni-V layered double

hydroxide nanosheets as

high-performance hybrid supercapacitor applicatior

Tyagi, Ankit

Amercian Chemical Society

Tyagi A, Joshi MC, Shah A, Thakur VK and Gupta RK., Hydrothermally tailored three-dimensional Ni-V layered double hydroxide nanosheets as high-performance hybrid supercapacitor applications, ACS Omega, Volume 4, Issue 2, 2019, pp.3257-3267

http://doi.org/10.1021/acsomega.8b03618

Downloaded from Cranfield Library Services E-Repository 